Manuscript Number: JEMA-D-18-01025R2

Title: Bottom-up approach in the assessment of environmental impacts and costs of an innovative anammox-based process for nitrogen removal

Article Type: Research Article

Keywords: partial nitritation-anammox; scale-up analysis; sustainable wastewater treatment; life cycle assessment (LCA); eco-efficiency; economic evaluation

Corresponding Author: Miss Andrea Arias,

Corresponding Author's Institution: University of Santiago de Compostela

First Author: Andrea Arias

Order of Authors: Andrea Arias; Iana Salim; Alba Pedrouso; Nicolás Morales; Anuska Mosquera-Corral; José Ramón Vázquez-Padín; Frank Rogalla; Gumersindo Feijoo; María Teresa Moreira

Abstract: In recent decades, the wastewater treatment sector has undergone a shift to adapt to increasing discharge limits. In addressing the evaluation of innovative technologies, it is necessary to determine the scale at which reliable and representative values of environmental impacts and costs can be obtained, ensuring that the system under assessment follows the direction of eco-efficiency.

This study has evaluated the environmental and economic indicators of an autotrophic nitrogen removal technology (ELAN囚) from laboratory conception ( $1.5 \mathrm{~L})$ to full scale (2 units of $115 \mathrm{~m} 3$ ) using the Life cycle Assessment (LCA) methodology. Indirect emissions related to electricity consumption are the main contributor in all impact categories except eutrophication. Electricity consumption referred to the functional unit ( $1 \mathrm{~m} 3$ of treated wastewater) decreases as the scale increases. The rationale behind this can be explained, among other reasons, by the low energy efficiency of small-scale equipment (pumps and aerators). Accordingly, a value of approximately $25 \mathrm{~kg}$ CO2eq per $\mathrm{m} 3$ of treated water is determined for laboratory scale, compared to only $5 \mathrm{~kg}$ co2eq per m3 at full-scale. When it comes to assessing the reliability of data, a pilot scale system of $0.2 \mathrm{~m} 3$ allowed to perform a trustworthy estimation of environmental indicators, which were validated at full-scale. In terms of operational costs, the scale of approximately $1 \mathrm{~m} 3$ provided a more accurate estimate of the costs associated with energy consumption. 


\section{Bottom-up approach in the assessment of environmental impacts and costs of an innovative anammox-based process for nitrogen removal}

Andrea Arias, ${ }^{\mathrm{a}, *}$ Iana Salim, Alba Pedrouso ${ }^{\mathrm{a}}$, Nicolás Morales ${ }^{\mathrm{b}}$, Anuska Mosquera-

Corral $^{\mathrm{a}}$, José Ramón Vázquez-Padín ${ }^{\mathrm{b}}$, Frank Rogalla ${ }^{\mathrm{b}}$, Gumersindo Feijoo ${ }^{\mathrm{a}}$, María Teresa

Moreira $^{\mathrm{a}}$

${ }^{a}$ Department of Chemical Engineering, School of Enginering, Universidade de Santiago de Compostela,

E-15782, Santiago de Compostela, Galicia, Spain

${ }^{\mathrm{b}}$ Aqualia, Guillarei WWTP, Camino de la Veiga s/n, E-36720, Tui, Spain

* Corresponding author. E-mail: andrea16_verin@hotmail.com

https://doi.org/10.1016/j.jenvman.2018.07.070

(C) <2018>. This manuscript version is made available under the CC-BY-NC-ND 4.0 license http://creativecommons.org/licenses/by-nc-nd/4.0/ 


\section{Graphical Abstract}

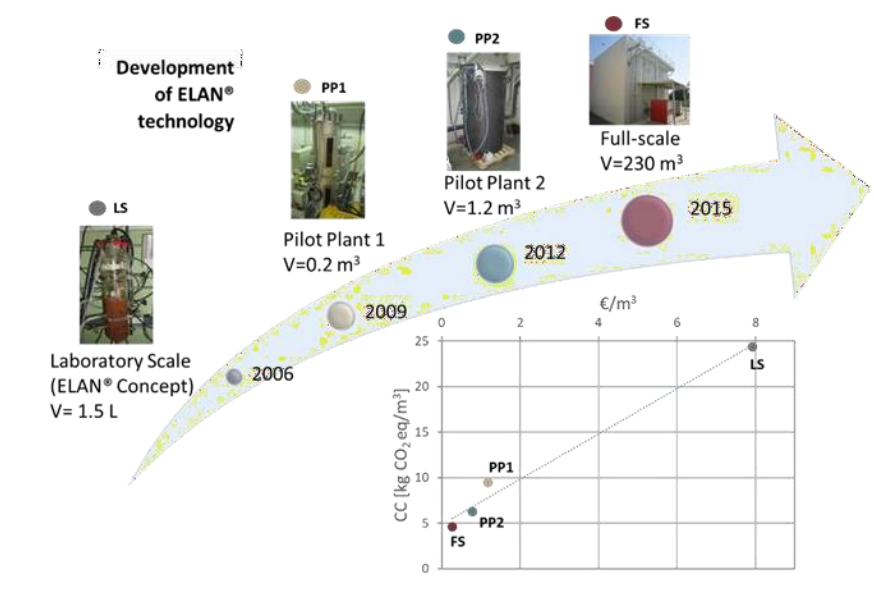

\section{Graphical Abstracts}




\section{Highlights:}

The sustainability of innovative technologies must be based on reliable inventory data.

The analysis at different scales is valuable for the decision-making process.

A pilot scale of $0.2 \mathrm{~m}^{3}$ is appropriate for the estimation of environmental impacts.

A minimum reactor volume of $1 \mathrm{~m}^{3}$ allow a reliable assessment of economic indicators 


\title{
Bottom-up approach in the assessment of environmental impacts and costs of an innovative anammox-based process for nitrogen removal
}

\author{
Andrea Ariass,", Iana Salimª, Alba Pedrouso ${ }^{a}$, Nicolás Morales ${ }^{\mathrm{b}}$, Anuska Mosquera- \\ Corral $^{\mathrm{a}}$, José Ramón Vázquez-Padín ${ }^{\mathrm{b}}$, Frank Rogalla ${ }^{\mathrm{b}}$, Gumersindo Feijoo ${ }^{\mathrm{a}}$, María Teresa \\ Moreira $^{\mathrm{a}}$ \\ ${ }^{a}$ Department of Chemical Engineering, School of Enginering, Universidade de Santiago de Compostela, \\ E-15782, Santiago de Compostela, Galicia, Spain \\ ${ }^{\mathrm{b}}$ Aqualia, Guillarei WWTP, Camino de la Veiga s/n, E-36720, Tui, Spain \\ * Corresponding author. E-mail: andrea16_verin@ @otmail.com
}




\section{Abstract}

In recent decades, the wastewater treatment sector has undergone a shift to adapt to increasing discharge limits. In addressing the evaluation of innovative technologies, it is necessary to determine the scale at which reliable and representative values of environmental impacts and costs can be obtained, ensuring that the system under assessment follows the direction of eco-efficiency.

This study has evaluated the environmental and economic indicators of an autotrophic nitrogen removal technology $\left(\mathrm{ELAN}^{\circledR}\right)$ from laboratory conception $(1.5 \mathrm{~L})$ to full scale (2 units of $115 \mathrm{~m}^{3}$ ) using the Life Cycle Assessment (LCA) methodology. Indirect emissions related to electricity consumption are the main contributor in all impact categories except eutrophication. Electricity consumption referred to the functional unit ( $1 \mathrm{~m}^{3}$ of treated wastewater) decreases as the scale increases. The rationale behind this can be explained, among other reasons, by the low energy efficiency of small-scale equipment (pumps and aerators). Accordingly, a value of approximately $25 \mathrm{~kg} \mathrm{CO}_{2 \text { eq }}$ per $\mathrm{m}^{3}$ of treated water is determined for laboratory scale, compared to only $5 \mathrm{~kg} \mathrm{CO}$ 2eq per $\mathrm{m}^{3}$ at full-scale. When it comes to assessing the reliability of data, a pilot scale system of $0.2 \mathrm{~m}^{3}$ allowed to perform a trustworthy estimation of environmental indicators, which were validated at full-scale. In terms of operational costs, the scale of approximately $1 \mathrm{~m}^{3}$ provided a more accurate estimate of the costs associated with energy consumption.

Keywords: partial nitritation-anammox; scale-up analysis; sustainable wastewater 


\section{Nomenclature}

Anammox

AOB

CAS

CC

CML

COD

DO

ELAN $^{\circledR}$

EP

FD

FET

FS

FU

HRT

HT

LCA

LCI

LS

MET

NOB

OD

OLAND

PMF

PN-AMX

POF

PP1

PP2

SBR

SCENA

TA

TET

VER

WD
Anaerobic Ammonium Oxidation

Ammonium-Oxidizing Bacteria

Conventional Activated Sludge System

Climate Change

Centre of Environmental Science of Leiden University

Chemical Oxygen Demand

Dissolved Oxygen

Autotrophic Nitrogen Removal, in Spanish

(ELiminación Autótrofa de Nitrógeno)

Eutrophication Potential

Fossil Depletion

Freshwater EcoToxicity

Full Scale

Functional Unit

Hydraulic Retention Time

Human Toxicity

Life Cycle Assessment

Life Cycle Inventory

Laboratory Scale

Marine EcoToxicity

Nitrite-Oxidizing Bacteria

Ozone Depletion

Oxygen Limited Autotrophic Nitrification-Denitrification

Particulate Matter Formation

Partial Nitritation-AnaMmoX

Photochemical Oxidation Formation

Pilot Plant 1

Pilot Plant 2

Sequencing Batch Reactor

Short Cut Enhanced Nutrient Abatement

Terrestrial Acidification

Terrestrial EcoToxicity

Volume Exchange Ratio

Water Depletion 
1

2

3

4

6

9 
1
2

\section{Introduction}

In the design of new processes and products, there is a growing demand to label them as sustainable from the earliest stages of their conception and development. Traditionally, the evolution of an innovative technology, from its conception to its implementation in the market, consists in overcoming a series of successive stages of development, where performance and operational conditions vary according to scale, making them comparable to conventional technologies. When introducing the environmental and economic perspectives, it is necessary to evaluate the scale level that allows reliable and representative values of environmental impacts and costs to be obtained, ensuring that the emerging technology is moving in the direction of ecoefficiency. This stage is critical, as it will mean the "abandonment" or "scaling up" of $R \& D$ activities to large-scale installation.

In the context of wastewater treatment, reducing the nitrogen load in the treated effluents is one of the main objectives to avoid excessive growth of algae in watercourses (eutrophication), toxicity by ammonia and decrease of dissolved oxygen, negatively affecting aquatic fauna and flora ( $\mathrm{Li}$ and Brett, 2012). In accordance with the European Water Framework Directive (2000/60/EC), a nitrogen discharge limit of 10 - 15 mg N/L applies for European wastewater treatment plants (WWTPs) in sensitive areas, provided that $70-80 \%$ of the total nitrogen in the influent is removed. This increased legislation restriction leads to the development of novel treatment technologies that need to be validated from an environmental and economic point of view (Machado et al., 2009; Wang et al., 2012). Several authors highlighted the balance between nitrogen removal and energy demand, which may lead to an increase in indirect greenhouse gas emissions depending on the complexity of the treatment scheme (Foley 
1 et al., 2010a; Lederer and Rechberger, 2010; Rodriguez-Garcia et al., 2011; Vidal et al., 2 2002).

Conventional nitrogen removal from wastewater is based on the biological nitrification-denitrification processes. Beyond the requirements of aeration and depending on the $\mathrm{COD} / \mathrm{N}$ ratio of the wastewater, the addition of an external carbon source may be required, which implies operational costs between $2.85-3.64 € / \mathrm{kg} \mathrm{N}$ removed. Furthermore, conventional technologies require extensive land use, increasing capital costs (Renzi et al., 2015).

The combination of partial nitritation-anammox (anaerobic ammonium oxidation) processes (Jetten et al., 2002; Mosquera-Corral et al., 2005) or partial nitrificationdenitrification (Renzi et al., 2015) are interesting alternatives to the conventional nitrification-denitrification processes. In recent years, new innovative technologies have been developed to incorporate these processes such as SCENA (Short Cut Enhanced Nutrient Abatement) (Renzi et al., 2015), OLAND (Oxygen Limited Autotrophic Nitrification-Denitrification) (Kuai and Verstraete, 1998) and ELAN ${ }^{\circledR}$ (autotrophic nitrogen removal in Spanish “ELiminación Autótrofa de Nitrógeno”) (Vázquez-Padín et al., 2014a). These technologies are applied for the treatment of the supernatant from the anaerobic sludge digesters which are nutrient rich side streams in the WWTP (VázquezPadín et al., 2014a, Longo et al. 2017). When ELAN ${ }^{\circledR}$ process is used for nitrogen removal, it can reduce oxygen requirements to $1.83 \mathrm{~kg} \mathrm{O}_{2} / \mathrm{kg} \quad \mathrm{N}_{\text {removed, with no }}$ consumption of organic matter and an outstandingly low biomass yield of $0.12 \mathrm{~kg}$ $\mathrm{VSS} / \mathrm{kg} \mathrm{N} \mathrm{N}_{\text {removed, }}$ compared to the remarkably higher values of $3.18 \mathrm{~kg} \mathrm{O}_{2} / \mathrm{kg} \mathrm{N}_{\text {removed, }}$, $4.9 \mathrm{~kg} \mathrm{COD} / \mathrm{kg} \mathrm{N}_{\text {removed }}$ and $2.11 \mathrm{~kg} \mathrm{VSS} / \mathrm{kg} \quad \mathrm{N}_{\text {removed }}$ in the case of nitrification/denitrification process (Vázquez-Padín et al., 2014a). 
1 With the aim of assessing the sustainability of water treatment technologies, the

2 Life Cycle Assessment (LCA) methodology arises as a good alternative because it

3 allows quantifying the potential environmental impacts throughout the entire cycle of a

4 product or process (ISO, 2006). This methodology has been widely used to evaluate the

5 efficiency of WWTPs or to study different treatment alternatives (Foley et al., 2010b;

$6 \quad$ Hospido et al., 2004; Lorenzo-Toja et al., 2016a). Beyond complying with water

7 discharge regulations, it must taken into account that among the different treatment

8 schemes, some might be considered advantages when applied to speficic cases, not only

9 considering environmental but also economic perspectives (Longo et al., 2017; LorenzoToja et al., 2016b; Rodriguez-Garcia et al., 2011). another has discredited the concept in some areas (Heijungs et al., 2010; Weidema, 2003). One of these weaknesses is attributed to the collection and validity of data required for the life cycle inventory (LCI). This stage is critical as it will compute the consumption of raw materials, chemicals, water and energy for each stage of the process, as well as emissions to air, water and soil (Finnveden, 2000; Lorenzo-Toja et al., 2016; Tillman, 2000). When the inventory data are executed from reliable data, it is possible to obtain accurate environmental impacts. This includes the need to make judgements based on the figures collected to assess the likely significance of the various impacts (Reap et al., 2008). However, uncertainty arises regarding the scale of development required. Furthermore, when the aim is to evaluate a technology under development, this drawback is even more important. The definition of the scale of development required, which provides reliable data for LCA, is therefore relevant to ensure the successful implementation of a bottom-up approach. 
1 The main objective of this study is to define the scale for which data collection in

2 the LCA methodology provide a reliable evaluation of a technology under development.

3 In particular, the assessment of an innovative wastewater treatment technology for $4 \quad$ nitrogen removal $\left(\mathrm{ELAN}^{\circledR}\right)$ from lab conception to full-scale was conducted. 


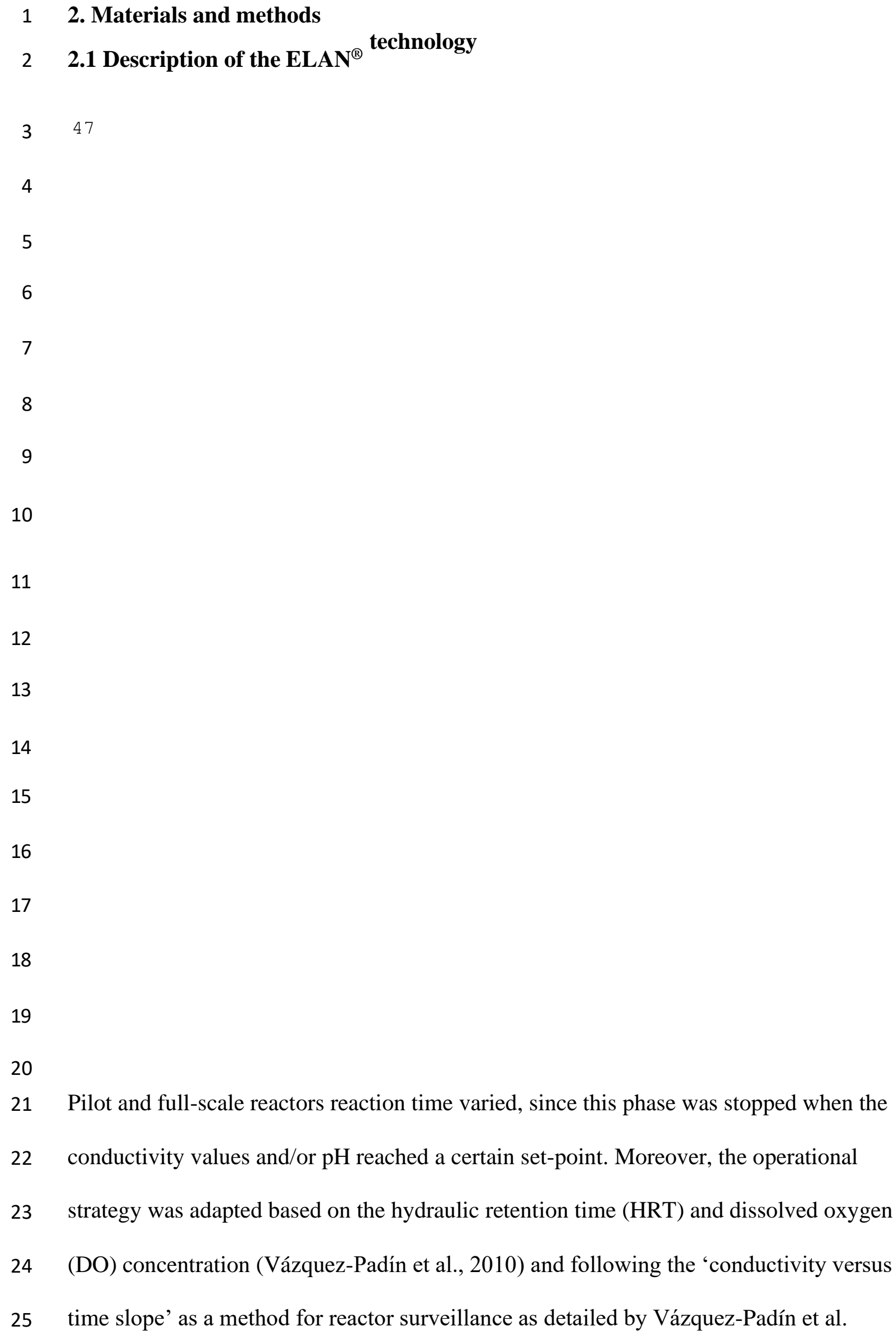

\subsection{Description of the ELAN ${ }^{\circledR}$ technology}

3

47

4

5

6

7

8

9

10

11

12

13

14

15

16

17

18

19

20

21 Pilot and full-scale reactors reaction time varied, since this phase was stopped when the

22 conductivity values and/or $\mathrm{pH}$ reached a certain set-point. Moreover, the operational

23 strategy was adapted based on the hydraulic retention time (HRT) and dissolved oxygen

24 (DO) concentration (Vázquez-Padín et al., 2010) and following the 'conductivity versus

25 time slope' as a method for reactor surveillance as detailed by Vázquez-Padín et al. 
T 1 artialateritationanhathamoxox (PN-AMX) processes in the same unit (Vázquez-Padín et

$\mathrm{h}$

e

E

L

A

$\mathrm{N}$

$(8$

$\mathrm{t}$

e

c

h

$\mathrm{n}$

o

o

g

y

c

o

$\mathrm{m}_{4}^{48}$

50

b1

al., 2010). In the partial nitritation process, the ammonium oxidizing bacteria (AOB) oxidize ammonium to nitrite, while the oxidation of nitrite to nitrate by the nitrite oxidizing bacteria (NOB) should be avoided (Vazquez-Padin et al., 2009). The anammox bacteria are capable of oxidizing ammonium to nitrogen gas using nitrite as electron acceptor, without the need of organic matter or oxygen (Dapena-Mora et al., 2004). Thus, in the $\mathrm{ELAN}^{\circledR}$ technology, nitrogen is autotrophically removed.

ELAN $^{\circledR}$ technology was developed in a sequencing batch reactor (SBR) with granular sludge (Figure 1). The establishment of aerobic and anoxic zones within the granule, depending on oxygen depth penetration, allow the operation in a single step (Morales 2015a). Four different reactor sizes (from $1.5 \mathrm{~L}$ to $115 \mathrm{~m}^{3}$ ) were analysed in this study (Table 1): Laboratory Scale (LS), Pilot Plant 1 (PP1), Pilot Plant 2 (PP2) and Full-scale (FS). The SBR operational cycle comprised the following stages: feeding, aerobic reaction, settling and withdrawal (Figure 1). The LS reactor, operated under the approach of the ELAN ${ }^{\circledR}$ process, operated at fixed-cycle duration of $3 \mathrm{~h}$ throughout the whole operational period cycles duration. The volume exchange ratio (VER), or ratio between the volume of effluent discharged and the volume of the reactor, was $25 \%$.

\footnotetext{
21 Pilot and full-scale reactors reaction time varied, since this phase was stopped when the conductivity values and/or $\mathrm{pH}$ reached a certain set-point. Moreover, the operational strategy was adapted based on the hydraulic retention time (HRT) and dissolved oxygen (DO) concentration (Vázquez-Padín et al., 2010) and following the 'conductivity versus time slope' as a method for reactor surveillance as detailed by Vázquez-Padín et al.
} 
1 (2014a). For this purpose the reactor is provided with a set of probes (conductivity,

$2 \mathrm{pH}, \ldots)$ connected to a control system. In this study, an average of cycle length was

3 considered, $6 \mathrm{~h}$ for PP1 and PP2 reactors, and $8 \mathrm{~h}$ for the FS reactor. The VER values of

4 each reactor was: $25 \%$ for PP1, $21 \%$ for PP2 and finally $44 \%$ for FS.

\section{$>$ FIGURE $1<$}

$>$ TABLE $1<$

\subsection{Approach for data collection in LCA methodology}

The LCA methodology according to a gate-to-gate approach was applied, following the ISO 14040 standard. The main impacts of WWTPs occur in the operational phase (Lundie et al., 2004). The construction phase was not taken into account because the infrastructure of each reactor is made up of different materials depending on the scale, availability and cost, which determines that emissions from this phase between small and full-scale are not comparable (Table 1). Similarly, the impacts associated with the decommissioning phase may be considered negligible (Foley et al., 2010b; Lorenzo- Toja et al., 2016b). Therefore, only the environmental impacts associated with the operational phase of each reactor were assessed in this study.

The functional unit (FU) should reflect the main function of the analysed system and be consistent with the goal and scope of the study (ISO, 2006). The most common FU used in LCA studies of WWTPs are the following: population equivalent (Gallego et al., 2008; Machado et al., 2007), kg N removed (Hauck et al., 2016; RodriguezGarcia et al., 2011) or $\mathrm{m}^{3}$ of treated wastewater (Hospido et al., 2012; Pasqualino et al., 2011). Under the approach of different scales, population equivalent does not apply in the LS, PP1 or PP2 scenarios. Consequently, one cubic meter (1 $\mathrm{m}^{3}$ ) of treated wastewater was selected as FU, which can be a straightforward solution when 
1 comparing different scales of operation. Moreover, a sensitivity analysis was performed

2 considering a FU of $\mathrm{kg} \mathrm{N}$ removed for benchmarking of the environmental outcomes.

The LCI has been developed with primary data from the laboratory scale, two pilot plant reactors and full- scale reactor, obtained during the different stages of development of the $\mathrm{ELAN}^{\circledR}$ process (Tables 2, 3, 4 and 5, respectively). Laboratory scale reactor was operated in the University of Santiago de Compostela, while pilots and full scale ELAN ${ }^{\circledR}$ reactors were operated in the Guillarei WWTP (Northwest of Spain), where the pilots and full scale ELAN ${ }^{\circledR}$ reactors are operated by Aqualia, since 2012 and 2015, respectively.

$>$ TABLE $2<$

$>$ TABLE 3<

$>$ TABLE $4<$

$>$ TABLE $5<$

Emissions to air (NO, $\mathrm{N}_{2} \mathrm{O}$ and $\mathrm{CO}_{2}$ ) were calculated according to Kampschreur et al. (2008) and Morales et al. (2015a). The power consumption of the reactors has been calculated according to the operating time and power of the pumps used. The Ecoinvent v3.2 database for the Spanish electricity production and import/export mix process was updated for 2016 with data from the annual report of Red Eléctrica Española (2016). In Spain, WWTPs use medium-voltage electricity (Lorenzo-Toja et al., 2016); thus, the high voltage electricity was converted to medium voltage, considering emissions to air and losses in transport (Dones et al., 2007).

\subsection{Assessment methodology and impact categories}

SimaPro v.8.2 software was used for the impact assessment. Two different assessment methods were used to provide the most characteristic environmental impacts 
1 of WWTPs (Rodriguez-Garcia et al., 2011). Eutrophication potential (EP) was

2 calculated using the CML method (Guinée, 2002). Climate change (CC), ozone

3 depletion (OD), terrestrial acidification (TA), photochemical oxidation formation

4 (POF), particulate matter formation (PMF), human toxicity (HT), terrestrial ecotoxicity

5 (TET), freshwater ecotoxicity (FET), marine ecotoxicity (MET), water depletion (WD)

6 and fossil depletion (FD) were calculated with the ReCiPe midpoint method (Goedkoop

7 et al., 2009).

in this study. In addition, since there is no addition of chemicals during the operation of the reactors, the costs associated with chemical consumption are not considered

22 (Vazquez Padin et al., 2014b).

\section{5 . Uncertainty analysis methodology}


1 The management of WWTPs faces variable operating conditions, flows and

2 composition of the flow to be treated, which can strongly influence the results of the

3 LCA studies (Yoshida et al., 2014). The most likely factors of uncertainty are: i)

4 uncertainty of parameters such as calibration of measurement equipment, human errors

5 or mismatches between different measurements of the same parameter and ii)

6 uncertainty associated to the background processes including in the databases, such as

7 electricity consumption (Huijbregts, 2002). In this study, the Monte Carlo uncertainty

8 method included in the SimaPro 8.2 software was applied. In this method, four types of

9 probability can be considered: uniform, triangular, normal and lognormal (Fantin et al.,

10 2015). For the background parameters (Ecoinvent v3.2 database), the lognormal is the

11 default selected probability distribution, while for the water characterization parameters

12 the normal distribution was selected. According to other studies (Guo and Murphy, 2012;

13 Longo et al., 2017), the Monte Carlo analysis was performed with 1,000 iterations at a 95\% significance level. 


\section{3. Results}

\section{3.1. Environmental and economic profiles}

3

4

5 the different environmental categories is the energy consumption, mainly associated with

6 the aeration process (Tables 2 to 5), which has a drastic effect when considering the scale

7 of the reactor, since at small scale (corresponding to the early stages of technology

8 development), the equipment used (pumps and aerators) is overdimensioned, that render

9 into larger electricity consumption, and therefore, leading to much higher impacts (Figure 2).

\section{$>$ TABLE $6<$}

As the scale increases, energy consumption is reduced. The reduction from PP1 to FS is not very high, approximately $9 \%$. This reduction is more important when the scale is increased from LS to FS (75\%), which is attributed to the overdimensioning of pumps and aerators used at small scale.

This reduction of energy translates into a lower impact in the different impact categories which are energy dependent (Table 6). The impact reduction is the same for all categories (about $75 \%$ from LS to FS) except for the climate change category.

In the climate change category, the impact is provoked by the non biogenic $\mathrm{CO}_{2}$ emited from fuel fossil combustion. The emissions are reduced as the scale increases from $55 \%$ in LS to $10 \%$ for FS (Figure 2a). In PP1, PP2 and FS, the emissions values are very similar, with impact reductions from 10 to $20 \%$ (Figure 2a). 
1 Considering that the final objective of a WWTP is to reduce the organic load and

2 eutrophication impact, one of the environmental categories that arises as essential is the eutrophication potential. This category does not depend on energy consumption, and compared to the other impact categories, the values show an opposite trend and change significantly among configurations (Figure 2b). The LS has lower eutrophication potential (15\%) due to the composition of the wastewater fed into the reactor with a lower concentration of N, about $77 \%$ in comparison to the FS (Vazquez-Padin et al., 2009). For this reason, the obtained result for LS in this EP category is not realistic enough to be compared with that from the other pilot or full-scale reactors. For the PP1, PP2 and FS systems, the impact is very similar approximately of $30 \%$. These reactors treated the reject water from sludge digester in the Guillarei municipal WWTP and the removal of compounds like COD, TN (inorganic and organic) or phosphorus that generate impact in this category was considered for the calculation (Table 2 to Table 5). Thus, the comparison in the eutrophication category is viable only between the pilot and the fullscale reactors. As the ELAN $^{\circledR}$ process accomplishes nitrogen removal it would be interesting to benchmark the eutrophication it "reduces" in comparison with a conventional system operated for the same purpose, or just the effect, on the secondary treatment of the WWTP where the reject water from the sludge anaerobic digester is recycled, but it is beyond the scope of this study.

The effect on the human toxicity category is associated with the indirect emissions from the electricity production. In Figure 2c, it can be seen that LS has the major impact and for the PP1, PP2 and FS, this impact decreases with size. The reduction from LS to PP1 is $66 \%$ whereas HT impact is further decreased to $75 \%$ in FS.

Since there is no chemical consumption and the amount of sludge produced can be considered negligible (Vazquez Padin et al., 2014a), only operational costs related to 
1 electricity consumption in the reactors evaluated for ELAN® process development were analysed for the economic assessment. The electricity costs are represented in Figure 3 per one cubic meter of treated wastewater $\left(€ / \mathrm{m}^{3}\right)$, ranging from $8 € / \mathrm{m}^{3}$ (LS) to $0.3 € / \mathrm{m}^{3}$ (FS). These values are related to the climate change impacts of each reactor.

\section{$>$ FIGURE 3<}

\subsection{Uncertainty analysis results}

The statistical parameters of the Monte Carlo analysis for each reactor are shown in the supplementary material (Tables S.1 to S.4). In these tables, the mean values, median, standard deviation, coefficient of variation and standard error of the mean for each reactor are calculated. The uncertainty for the different environmental categories, can be represented in terms of the coefficient of variation defined as the relationship between the variability of the data concerning the standard deviation (Figure 4). The uncertainty is independent of the scale of the installation, as the same behaviour was found for all categories. Furthermore uncertainty was less than $30 \%$ for all categories with the exception of the "Human toxicity" category. The value of the environmental impact derived from this category depends to a large extent on the electricity production process considered and, more specifically, on the effect of the heavy metals associated with the process. The electricity consumption of the different treatment systems was primary data, but the profile and processes of electricity generation are secondary (obtained from the Ecoinvent v.3.2 database). The Ecoinvent processes tend to have a high uncertainty that affects the final results and for this reason the uncertainty is higher in this category from $74 \%$ in PP2 to $85 \%$ in LS. Consequently, the data obtained for the environmental impact study of the ELAN ${ }^{\circledR}$ technology according to the scale of the reactor can be considered representative. 
2

3

4

\section{Discussion}

Currently, extrapolation of laboratory scale emissions to industrial facilities can only be estimated, not measured. However, estimation using bottom-up techniques (e.g., using scale factors) can produce overestimated impacts. By selecting an appropriate scale of development, we can produce inventories that are accurate in the sense of being neither over nor underestimated to the extent possible, and where uncertainties are reduced. When LCA is used to support decision making, confidence in LCI data needs to be assured. In ideal circumstances, inventory data are validated and uncertainty can be quantified. Obtaining reliable inventory data, clearly described and accurately reported, is not easy and can seriously hamper the implementation of LCA. The use of published inventory databases may be useful only for background processes, but not especially when it is an innovative technology in its early stages of development. This will help to understand the magnitude of the environmental impacts and are a key element in reporting on progress and monitoring changes associated with improvement actions towards objectives.

\subsection{Categories dependent on electricity consumption}

In this study, the indirect emissions caused by energy consumption are presented in all categories except eutrophication. It should be noted that electricity emissions depend

on the electricity mix of each country. In Spain, electricity production is represented by $59.2 \%$ of non-renewable energy and $40.8 \%$ of renewable energy (REE, 2016).

As indicated in section 2.1, the ELAN ${ }^{\circledR}$ technology includes a number of energyconsuming operational stages (feeding, aeration and withdrawal) (Figure 1). Energy consumption should be optimised, as it is a parameter that directly affects climate 
1 change and the major contributor of the different environmental categories. Electricity

2 consumption decreases as the scale increases (FS $<\mathrm{PP} 2<\mathrm{PP} 1<\mathrm{LS})$ (Figure 2).

3 Consequently, the impacts should be reduced as the scale increases. In the LS or PP1,

4 the installed pumps and aerators were oversized. Accordingly, for the analysis of the LS

5 and PP1 reactors, it was not considered equipment which presented reduced energy

6 consumption. The reduction of LS to PP1 is significant of $56 \%$ while the reduction of

7 PP1 to FS represents only 9\%. This means that the environmental study would be

8 adequate from a reactor volume of $0.2 \mathrm{~m}$ if the process is optimised in terms of

9 installed power (pumps and aerators).

$10 \quad 46$
47

21 ELAN $^{\circledR}$ full-scale reactor, the emissions responsible for the climate change amount to

$224.62 \mathrm{~kg} \mathrm{CO} 2 \mathrm{eq} / \mathrm{m}$. 3 This suggests that the use of an $\mathrm{ELAN}^{\circledR}$ system instead of a

23 conventional nitrification/denitrification process in the sidestream could reduce

24 emissions by approximately $57 \%$. Even for innovative alternatives such as the

25 SHARON-Anammox technology (PN-AMX processes in separate units), the estimated 
D 1 impngfrom the majoA

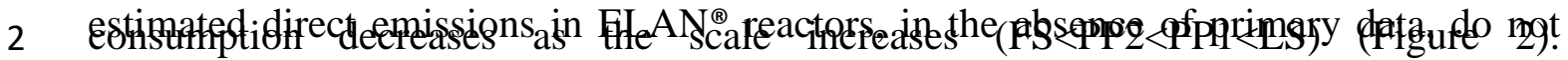

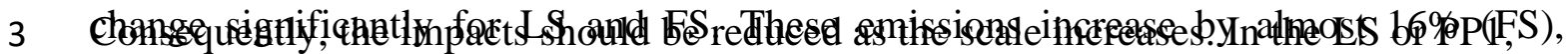

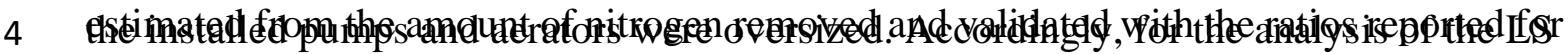

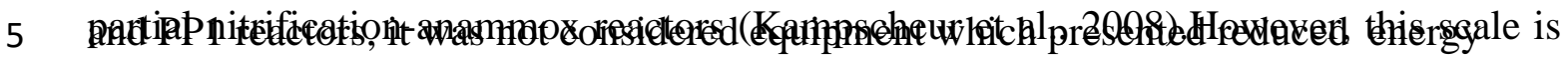
not relevant for comparison with the indirect emissions, which show an increase of approximately $55 \%$ from LS to FS reactors.

The conventional nitrification/denitrification processes have a higher electricity consumption than the $\mathrm{ELAN}^{\circledR}$ technology, which is mainly attributed to the energy use in the aeration process. The indirect emissions associated with the climate change category in conventional reactors are $10.37 \mathrm{~kg} \mathrm{CO}_{2} \mathrm{eq} / \mathrm{m}$ of treated effluent while in the

21 ELAN $^{\circledast}$ full-scale reactor, the emissions responsible for the climate change amount to

$224.62 \mathrm{~kg} \mathrm{CO}_{2} \mathrm{eq} / \mathrm{m}$. This suggests that the use of an ELAN ${ }^{\circledR}$ system instead of a

23 conventional nitrification/denitrification process in the sidestream could reduce

24 emissions by approximately $57 \%$. Even for innovative alternatives such as the

25 SHARON-Anammox technology (PN-AMX processes in separate units), the estimated 
1 direct emissions are comparatively higher (up to $13 \%$ for $\mathrm{NO}$ and $\mathrm{N}_{2} \mathrm{O}$ ) than in the

2 ELAN $^{\circledR}$ technology where PN-AMX takes place in a single unit (Kampschreur et al.,

3

4

5

6

7 2008; Van Dongen et al., 2001). The fact that low CC impact is produced indicates that the treatment costs will be presumably lower in the case of the $\mathrm{ELAN}^{\circledR}$ as well.

\subsection{Sensitivity analysis of the functional unit}

The functional unit is a relevant decision in the LCA methodology. The selection of two different functional units (one cubic meter of treated wastewater and $\mathrm{kg} \mathrm{TN}$ removed) for the eutrophication and climate change categories (Figure 5a and 5b) were investigated.

The category of climate change was considered because it is strongly dependent on indirect emissions of greenhouse gases derived from the consumption of electrical energy, especially during secondary treatment (Lorenzo-Toja et al., 2016a,b). The consideration of eutrophization finds its interest in the operation of nutrient removal systems for wastewater treatment. It has been reported that the implementation of a nitrificationdenitrificacion process implies a 54-58\% reduction in eutrophication potential in the mainstream of WWTPs (Larsen et al., 2007). However, ELAN ${ }^{\circledR}$ reactors upon being a sidestream (reactors in the sludge line) such as other reactors located in the same place, do not lead to the discharge of the treated effluent directly into water bodies, but it is treated its treated in a subsequent phosphorus recovery unit (struvite

precipitation) or it is returned to the headwaters of the WWTP (Morales et al., 2015b), causing no increase of the nitrogen load of the mainstream and improving as a consequence the quality of the effluent from the WWTP. Moreover, the only impact category that is not fundamentally dependent on electricity consumption is eutrophication potential. Figures $4 \mathrm{a}$ and $4 \mathrm{~b}$ show that the values of the two functional 
1 units are very similar. Therefore, the choice of another functional unit would not change

2 the results of this study and the appropriate size for an environmental study would

3

4

5 remain the same $\left(0.2 \mathrm{~m}^{3}\right.$ reactor $)$.

\subsection{Data representativeness and bottom-up techniques}

As indicated above, the composition of wastewater presents a significant degree of variability, which may condition the results of the LCA study. It is therefore important to validate the data, but sometimes this is difficult because a large number of measures are required and aggregation of the data into impact categories can mean the loss of a precise approach (Balkema et al., 2002). Figure 2 shows the impact assessment profile for the $\mathrm{CC}, \mathrm{EP}$ and $\mathrm{HT}$ categories per functional unit $\left(1 \mathrm{~m}^{3}\right.$ of wastewater) in relation to the standard error of the mean, i.e. the standard deviation of all possible data in relation to the number of iterations of the Monte Carlo analysis. For energy-dependent categories such as CC and HT, the most significative deviations occur at LS (Figure 2), this is due to the electricity consumption at this stage which is higher than in the other reactors. The uncertainty is reduced from approximately $78 \%$ in LS to $2 \%$ in FS. This is in agreement with the results of the study presented in the results section. Finally, in the EP category the variation between the different reactors is similar., which is attributed to its higher dependence on the effluent and influent conditions (COD, TN or TP). These parameters are actual measurements and in this study show less deviation and more consistency than the electrical process (background process).

There are profuse literature reports on large-scale environmental assessment of WWTP, but little information is available on the environmental and economic analysis of innovative technology under development. This study allows validating the bottomup techniques strategy in LCA studies, specifically for the analysis of innovative technologies in the field of wastewater treatment and management. Therefore, it is 
1 important to know at what point in the development of a technology it makes sense to

2 do LCA analyses in order to assess whether the technology is economically and

3 environmentally friendly. In addition, the hotspots of the final environmental impact can

4 be precisely known in the early stages of technology development, so that operational

5 strategies or design modifications can be introduced at later scales to minimize the final

6 impact.

7 In short, this paper indicates the turning point at the scale level from which the decision is made as to whether a technological innovation can be feasible or not and, therefore, continue the bottom-up strategy.

\subsection{Economic aspects}

To compare the magnitude of the cost presented by the $\mathrm{ELAN}^{\circledR}$ technology, the SCENA system (as an example of innovative technology applied at sidestream conditions) and the conventional activated slugde system (CAS) have been considered. For SCENA, the corresponding cost of electricity is $0.52 € / \mathrm{m}^{3}$ and it is double for CAS $\left(1.09 € / \mathrm{m}^{3}\right)$ (Renzi et al., 2015). However, the cost associated with ELAN ${ }^{\circledR}$ is lower $(0.27$ $€ / \mathrm{m}^{3}$ ) than those from SCENA and CAS (Renzi et al., 2015). SCENA system is more complex than $\mathrm{ELAN}^{\circledR}$ technology as it comprises a fermentation unit, a screw press filter and finally, a batch sequencing reactor (Frison et al., 2014). In this case, as the sequencing batch reactor is the unit where partial nitrification-denitrification takes place, this reactor was taken into account in the estimation of costs related energy consumption. An important question is to determine the level of technological development required for the estimation of accurate costs. In this case, the economic data shown in Figure 3 are similar for PP2 and FS. The PP1 value remains high compared to PP2 and FS, as it represents approximately $12 \%$ of the energy consumption 
1 cost. Therefore, an appropriate reactor volume to obtain an economic evaluation in

2 terms of operational costs is approximately $1 \mathrm{~m}^{3}$.

3

4

5

6

7

8

9

10

11

12

When it comes to evaluate the economic aspects for only one technology, it makes sense to use electricity-related operating costs for comparison. However, for different technologies, the implementation costs of one or the other technology are likely to be very different. One of the advantages that $\mathrm{ELAN}^{\circledR}$ process stands out from other technologies on the market is that cheaper robust probes are used and the reactor configuration is simpler than other options (Morales et al, 2015b).

\section{Conclusions}

After applying the LCA methodology to explore the minor reactor volume which provides reliable results to evaluate impacts from a developed technology a minimum volume of $0.2 \mathrm{~m}^{3}$ was selected. An environmental assessment can be made when the energy consumption (pumps and aerators)is optimised for the reactor size. This is because in eutrophication, which is the category that does not depend on energy consumption, the impact is practically the same for PP1, PP2 and FS. Therefore, it is possible to make an environmental assessment of the PP1 level. Regarding to the operational cost, the volume adequate to get an economic evaluation is approximately $1 \mathrm{~m}^{3}$.

\section{Acknowledgements}

This research was supported by the UE projects: Pioneer_STP (PCIN-2015-22 (MINECO)/ID199 (WaterJPI) and Run4Life (730285-1). The authors (A. Arias, I. Cámara Salim, A. Pedrouso, A. Mosquera-Corral, G. Feijoo and M.T. Moreira) belong to the Galician Competitive Research Group (GRC ED431C 2017/29) and to the CRETUS Strategic Partnership (AGRUP2015/02). The authors gratefully acknowledge the staff of Guillarei WWTP and 'Consorcio de Augas do Louro' for their assistance. 


\section{References}

2 Balkema, A.J., Preisig, H.A., Otterpohl, R., Lambert, F.J.D., 2002. Indicators for the sustainability assessment of wastewater treatment systems. Urban Water 4, 153161.

Dapena-Mora, A., Campos, J.L., Mosquera-Corral, A., Jetten, M.S.M., Méndez, R., 2004. Stability of the ANAMMOX process in a gas-lift reactor and a SBR. J. Biotechnol. $110,159-170$.

Dones R., Bauer C., Bolliger R., Burger B., Faist Emmenegger M., Frischknecht R., Heck T., Jungbluth N., Röder A., T.M., 2007. Life cycle inventories of energy systems: results of current systems in Switzerland and other UCTE countries. Ecoinvent Rep.5.

EC, 1991. Directive 91/271/1991 ECC of 21 May 1991 concerning urban waste water treatment. Official Journal of the European Communities L 135, 40-52.

EU, 2000. Directive 2000/60/EC of 23 October 2000 establishing a framework for community action in the field of water policy. Official Journal of the European Communities L. 327, 1-72.

Fantin, V., Giuliano, A., Manfredi, M., Ottaviano, G., Stefanova, M., Masoni, P., 2015. Environmental assessment of electricity generation from an Italian anaerobic digestion plant. Biomass and Bioenergy 83, 422-435.

Finnveden, G., 2000. On the limitations of life cycle assessment and environmental systems analysis tools in general. Int. J. Life Cycle Assess. 5, 229-238.

Foley, J., de Haas, D., Hartley, K., Lant, P., 2010a. Comprehensive life cycle inventories of alternative wastewater treatment systems. Water Res. $\quad 44,1654-$ 1666. 
1 Foley, J.M., Rozendal, R.A., Hertle, C.K., Lant, P.A., 2010b. Life Cycle Assessment of 2 High-Rate Anaerobic Treatment, Microbial Fuel Cells, and Microbial Electrolysis

3

4 Cells. Sci. Technol 44, 3629-3637.

Guo, M., Murphy, R.J., 2012. LCA data quality: Sensitivity and uncertainty analysis. Sci. Total Environ. 435-436, 230-243.

Huijbregts, M., 2002. Uncertainty and variability in environmental life-cycle assessment. Int. J. Life Cycle Assess. 7, 173.

Nicola Frison, Stefano Longo, Daniele Renzi and Francesco Fatone, 2015. "Short-Cut Enhanced Nutrients Abatement (SCENA) From Reject Water: Moving The System Into Practice”. Nutrient Removal and Recovery (NRR) Congress. International Water Association (IWA).

Gallego, A., Hospido, A., Moreira, M.T., Feijoo, G., 2008. Environmental performance of wastewater treatment plants for small populations. Resour. Conserv. Recycl. 52, 931-940.

Goedkoop, M., Heijungs, R., Huijbregts, M., Schryver, A. De, Struijs, J., Zelm, R. Van, 2009. ReCiPe 2008. Potentials 1-44.

Guinée, J., 2002. Handbook on Life Cycle Assessment Operational Guide to the ISO Standards. Environ. Impact Assess. Rev. 23, 129-130.

Heijungs, R., Huppes, G., Guinée, J.B., 2010. Life cycle assessment and sustainability analysis of products, materials and technologies. Toward a scientific framework for sustainability life cycle analysis. Polym. Degrad. Stab. 95, 422-428.

Hospido, A., Moreira, M.T., Fernández-Couto, M., Feijoo, G., 2004. Environmental performance of a municipal wastewater treatment plant. Int. J. Life Cycle Assess. 
1 Hospido, A., Sanchez, I., Rodriguez-Garcia, G., Iglesias, A., Buntner, D., Reif, R., Moreira, M.T., Feijoo, G., 2012. Are all membrane reactors equal from an environmental point of view? Desalination. 285, 263-270.

ISO, 2006. ISO 14040. Environmental management - life cycle assessment - principles and framework. International Standards Organization.

Jetten, M.S.M., Schmid, M., Schmidt, I., Wubben, M., van Dongen, U., Abma, W., Sliekers, O., Revsbech, N.P., Beaumont, H.J.E., Ottosen, L., Volcke, E., Laanbroek, H.J., Campos-Gomez, J.L., Cole, J., van Loosdrecht, M., Mulder, J.W., Fuerst, J., Richardson, D., van de Pas, K., Mendez-Pampin, R., Third, K., Cirpus, I., van Spanning, R., Bollmann, A., Nielsen, L.P., den Camp, H.O., Schultz, C., Gundersen, J., Vanrolleghem, P., Strous, M., Wagner, M., Kuenen, J.G., 2002. Improved nitrogen removal by application of new nitrogen-cycle bacteria. Rev. Environ. Sci. Biotechnol. 1, 51-63.

Kampschreur, M.J., van der Star, W.R.L., Wielders, H.A., Mulder, J.W., Jetten, M.S.M., van Loosdrecht, M.C.M., 2008. Dynamics of nitric oxide and nitrous oxide emission during full-scale reject water treatment. Water Res. 42, 812-826.

Kuai, L., Verstraete, W., 1998. Ammonium Removal by the Oxygen-Limited Autotrophic Nitrification-Denitrification System Ammonium Removal by the Oxygen-Limited Autotrophic Nitrification-Denitrification System. Appl. Environ. Microbiol. 64, $4500-4506$.

Larsen, H.F., Hauschild, M., Wenzel, H., Almemark, M., 2007. Homogeneous LCA methodology agreed by NEPTUNE and INNOWATECH. Denmark 1-34.

Lederer, J., Rechberger, H., 2010. Comparative goal-oriented assessment of conventional and alternative sewage sludge treatment options. Waste Manag. 30, 
2

3

4

Li, B., Brett, M.T., 2012. The impact of alum based advanced nutrient removal processes on phosphorus bioavailability. Water Res. 46, 837-844

Longo, S., Frison, N., Renzi, D., Fatone, F., Hospido, A., 2017. Is SCENA a good approach for side-stream integrated treatment from an environmental and economic point of view? Water Res. 125, 478-489.

Lorenzo-Toja, Y., Alfonsín, C., Amores, M.J., Aldea, X., Marin, D., Moreira, M.T., Feijoo, G., 2016a. Beyond the conventional life cycle inventory in wastewater treatment plants. Sci. Total Environ. 553, 71-82.

Lorenzo-Toja, Y., Vázquez-Rowe, I., Amores, M.J., Termes-Rifé, M., Marín-Navarro, D., Moreira, M.T., Feijoo, G., 2016b. Benchmarking wastewater treatment plants under an eco-efficiency perspective. Sci. Total Environ. 566-567, 468-479.

Lundie, S., Peters, G.M., Beavis, P.C., 2004. Life Cycle Assessment for Sustainable

4 Metropolitan Water Systems Planning. Environ. Sci. Technol. 38, 3465-3473.

15 Machado, A.P., Urbano, L., Brito, A.G., Janknecht, P., Salas, J.J., Nogueira, R., 2007.

$\begin{array}{lll}16 & 58 & 23 \\ & 59 & \\ 17 & 60 & 24\end{array}$


L 1 ater łregłgent options for small and decentralized communities. Water Sci. Technol. i $56,15-22$

2 Li, B., Brett, M.T., 2012. The impact of alum based advanced nutrient removal

3 Machadges controllers design based on the relative gain array for a nutrient removal WWTP. 4 Longo, S., Frison, N., Renzi, D., Fatone, F., Hospido, A., 2017. Is SCENA a good Water Res. 43, 5129-5141.

Morales, N., Val Del Río, A., Vázquez-Padín, J.R., Gutiérrez, R., Fernández-González, $\mathrm{c}$ R., Icaran, P., Rogalla, F., Campos, J.L., Méndez, R., Mosquera-Corral, A., 2015a. 1 Influence of dissolved oxygen concentration on the start-up of the anammox-based process: ELAN ${ }^{\circledR}$ Water Sci. Technol. 72, 520-527.

a 
1 Morales, N., Val del Río, Á., Vázquez-Padín, J.R., Méndez, R., Mosquera-Corral, A.,

2 Campos, J.L., 2015b. Integration of the Anammox process to the rejection water and main stream lines of WWTPs. Chemosphere 140, 99-105.

Mosquera-Corral, A., González, F., Campos, J.L., Méndez, R., 2005. Partial nitrification in a SHARON reactor in the presence of salts and organic carbon compounds. Process Biochem. 40, 3109-3118.

Pasqualino, J.C., Meneses, M., Castells, F., 2011. Life Cycle Assessment of Urban Wastewater Reclamation and Reuse Alternatives. J. Ind. Ecol. 15, 49-63.

REE. Red Eléctrica de España, 2017. Avance del Informe del sistema elétrico español 2016. Red Eléctrica de España, Madrid.

Reap, J., Roman, F., Duncan, S., Bras, B., 2008. A survey of unresolved problems in life cycle assessment. Part 2: Impact assessment and interpretation. Int. J. Life Cycle Assess. 13, 374-388.

Renzi, D., Longo, S., Frison, N., Malamis, S., Katsou, E.,Fatone, F., 2015 Short-cut enhanced nutrient removal from anaerobic supernatants: Pilot scale results and full scale development of the S.C.E.N.A process. Sewage Treatment Plants. Economic Evaluation of Innovative Technologies for Energy Efficiency. IWA publishinig London, pp.1-94.

Rodriguez-Garcia, G., Molinos-Senante, M., Hospido, A., Hernández-Sancho, F., Moreira, M.T., Feijoo, G., 2011. Environmental and economic profile of six typologies of wastewater treatment plants. Water Res. 45, 5997-6010.

Tillman, A.-M., 2000. Significance of decision making for LCA methodology. Environ. Impact Assess. Rev. 20, 113-123.

Van Dongen, U., Jetten, M.S.M., Van Loosdrecht, M.C.M., 2001. The SHARON®- 
Anammox ${ }^{\circledR}$ process for treatment of ammonium rich wastewater. Water Sci.

2 Technol. 44, 153-160.

Vázquez-Padín, J.R., Pozo, M.J., Jarpa, M., Figueroa, M., Franco, A., Mosquera-Corral, A., Campos, J.L., Méndez, R., 2009. Treatment of anaerobic sludge digester effluents by the CANON process in an air pulsing SBR. J. Hazard. Mater. 166, $336-341$.

Vázquez-Padín, J., Mosquera-Corral, A., Campos, J.L., Méndez, R., Revsbech, N.P., 2010. Microbial community distribution and activity dynamics of granular biomass in a CANON reactor. Water Res. 44, 4359-4370.

Vázquez-Padín, J.R., Morales, N., Gutiérrez, R., Fernández, R., Rogalla, F., Barrio, J.P., Campos, J.L., Mosquera-Corral, A., Méndez, R., 2014a. Implications of full-scale implementation of an anammox-based process as post-treatment of a municipal anaerobic sludge digester operated with co-digestion. Water Sci. Technol. 69, 11511158.

Vazquez Padin, J.R., Morales, N., Icaran, P., Gutiérrez, R., Fernández González, R., Rogalla, F., Val del Río, Á., Campos, J.L., 2014b. Implantación del sistema ELAN para la eliminación sostenible de nitrógeno en la línea de retorno de la EDAR de Guillarei (Tui, Pontevedra). Retema 60-66.

Vidal, N., Poch, M., Marti, E., Rodriguez-Roda, I., 2002. Evaluation of the environmental implications to include structural changes in a wastewater treatment plant. J. Chem. Technol. Biotechnol. 77, 1206-1211.

Wang, X., Liu, J., Ren, N.Q., Duan, Z., 2012. Environmental profile of typical anaerobic/anoxic/oxic wastewater treatment systems meeting increasingly stringent treatment standards from a life cycle perspective. Bioresour. Technol. 126, 31-40. 
1 Weidema, B.P., 2003. Market information in life cycle assessment. Danish Minist.

2 Environ. 863, 147.

3 Yoshida, H., Clavreul, J., Scheutz, C., Christensen, T.H., 2014. Influence of data

4 collection schemes on the Life Cycle Assessment of a municipal wastewater $5 \quad$ treatment plant. Water Res. 56, 292-303.

6 Zang, Y., Li, Y., Wang, C., Zhang, W., Xiong, W., 2015. Towards more accurate life 7 cycle assessment of biological wastewater treatment plants: A review. J. Clean. 8 Prod. 107, 676-692. 


\section{Figure Captions}

Figure 1. Scheme of operational cycle in the reactors operated at different scale for the development of the ELAN $^{\circledR}$ process.

Figure 2. Comparison of environmental impacts obtained from the different reactor sizes:(including standard deviations): (a) Climate Change (CC) (b) Eutrophication Potential (EP) (c) Human Toxicity (HT) impacts.

Figure 3. Climate Change impact and cost per cubic meter of treated wastewater.

Acronyms: LS: $1.5 \mathrm{~L}, \mathrm{PP} 1: 0.2 \mathrm{~m}^{3}$, PP2: $1.2 \mathrm{~m}^{3}$ and FS: $97 \mathrm{~m}^{3}$

Figure 4. Coefficient of variation for each reactor.

Figure 5. a) Comparison between two different functional units $\left(1 \mathrm{~m}^{3}\right.$ of treated wastewater and $\mathrm{kg}$ TN removal) for the eutrophication category. b) Comparison between two different functional units $\left(1 \mathrm{~m}^{3}\right.$ of treated wastewater and $\mathrm{kg} \mathrm{TN}$ removal) for the climate change category. Acronyms: LS: $1.5 \mathrm{~L}, \mathrm{PP} 1: 0.2 \mathrm{~m}^{3}, \mathrm{PP} 2: 1.2 \mathrm{~m}^{3}$ and FS: $97 \mathrm{~m}^{3}$ 
ELAN $^{\circledR}$ TECHNOLOGY

SEQUENCING BATCH REACTOR

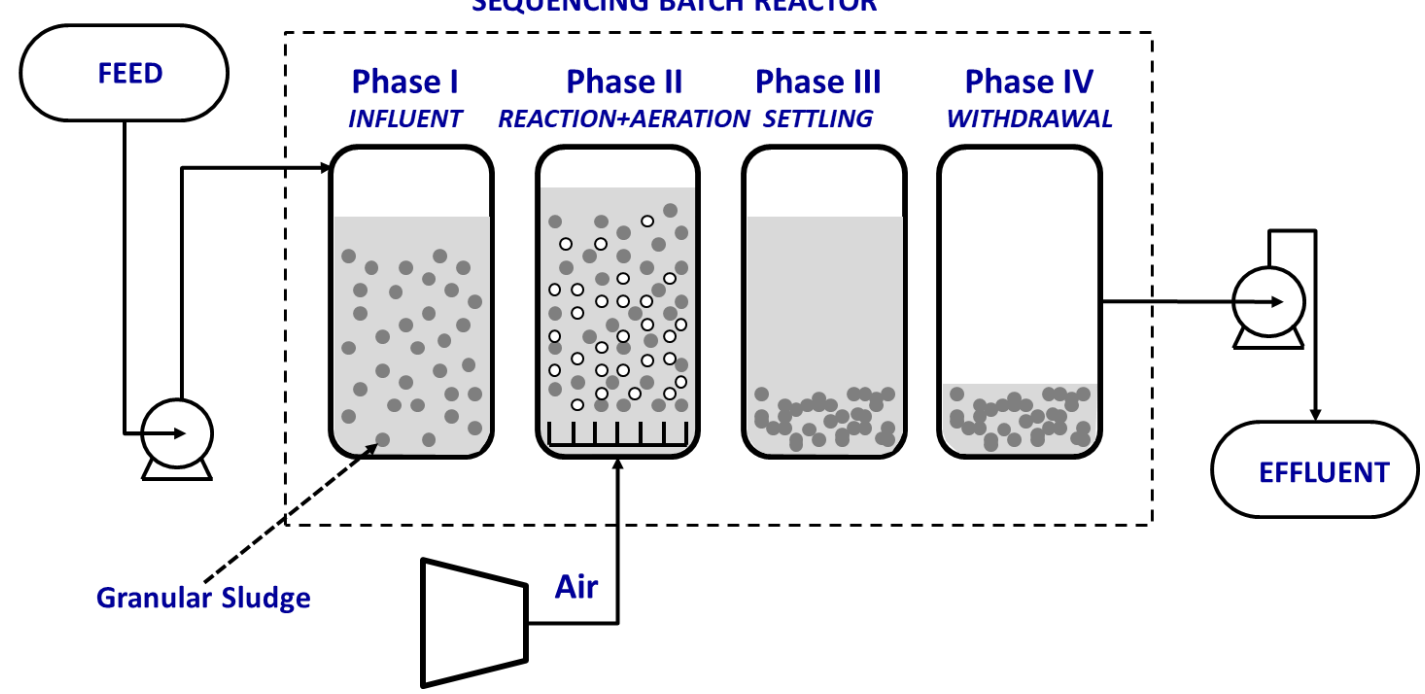

Figure 1 

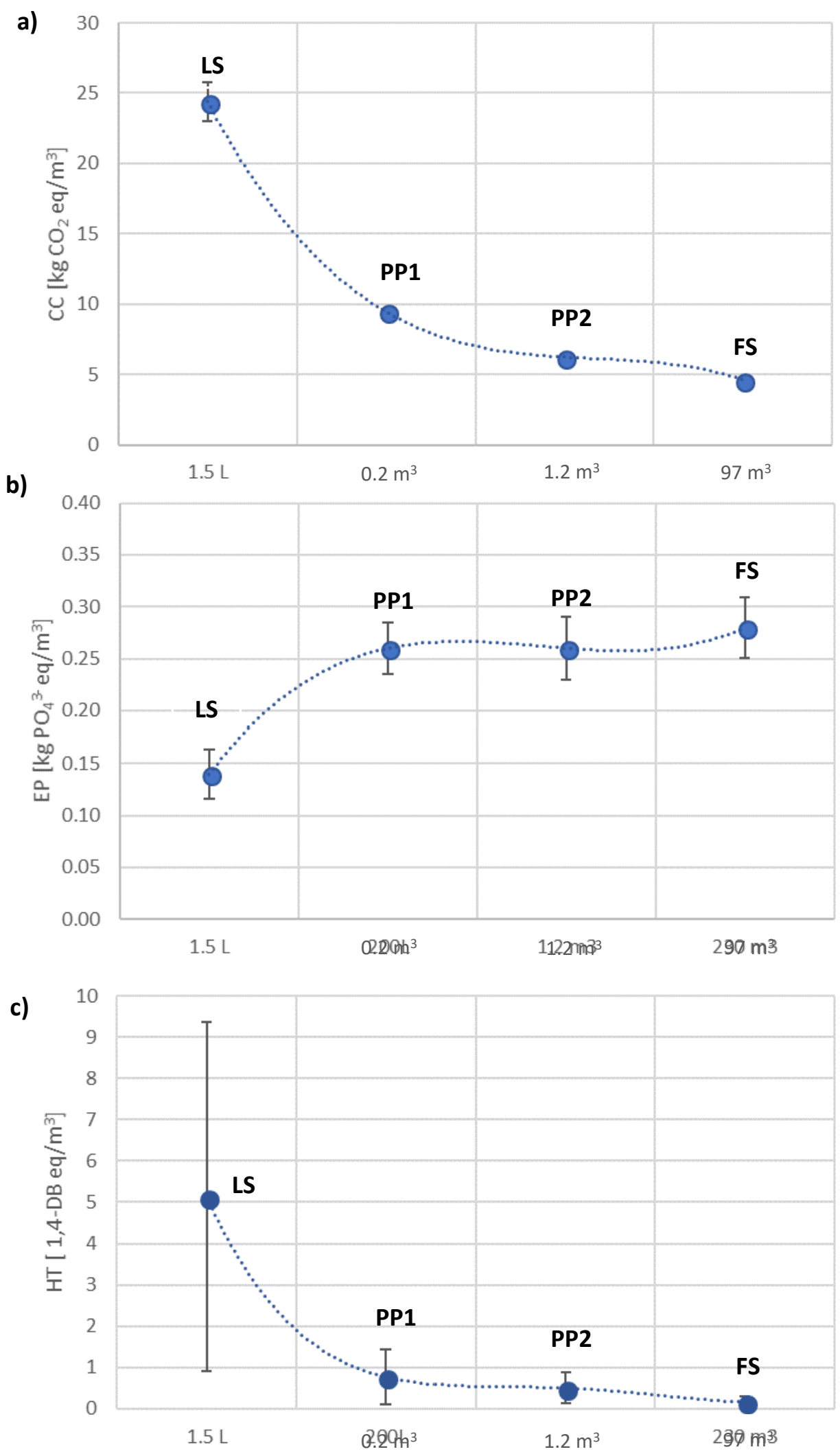

Figure 2 


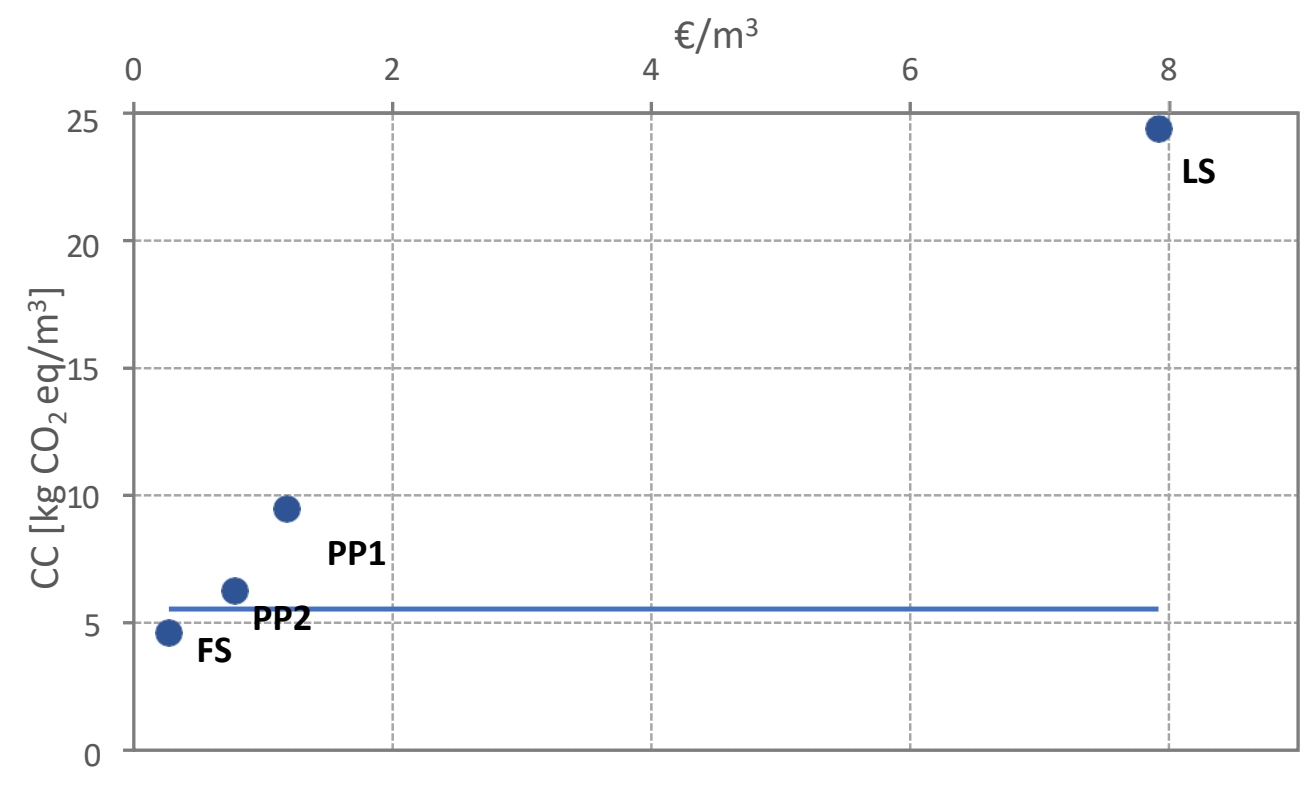

Figure 3 


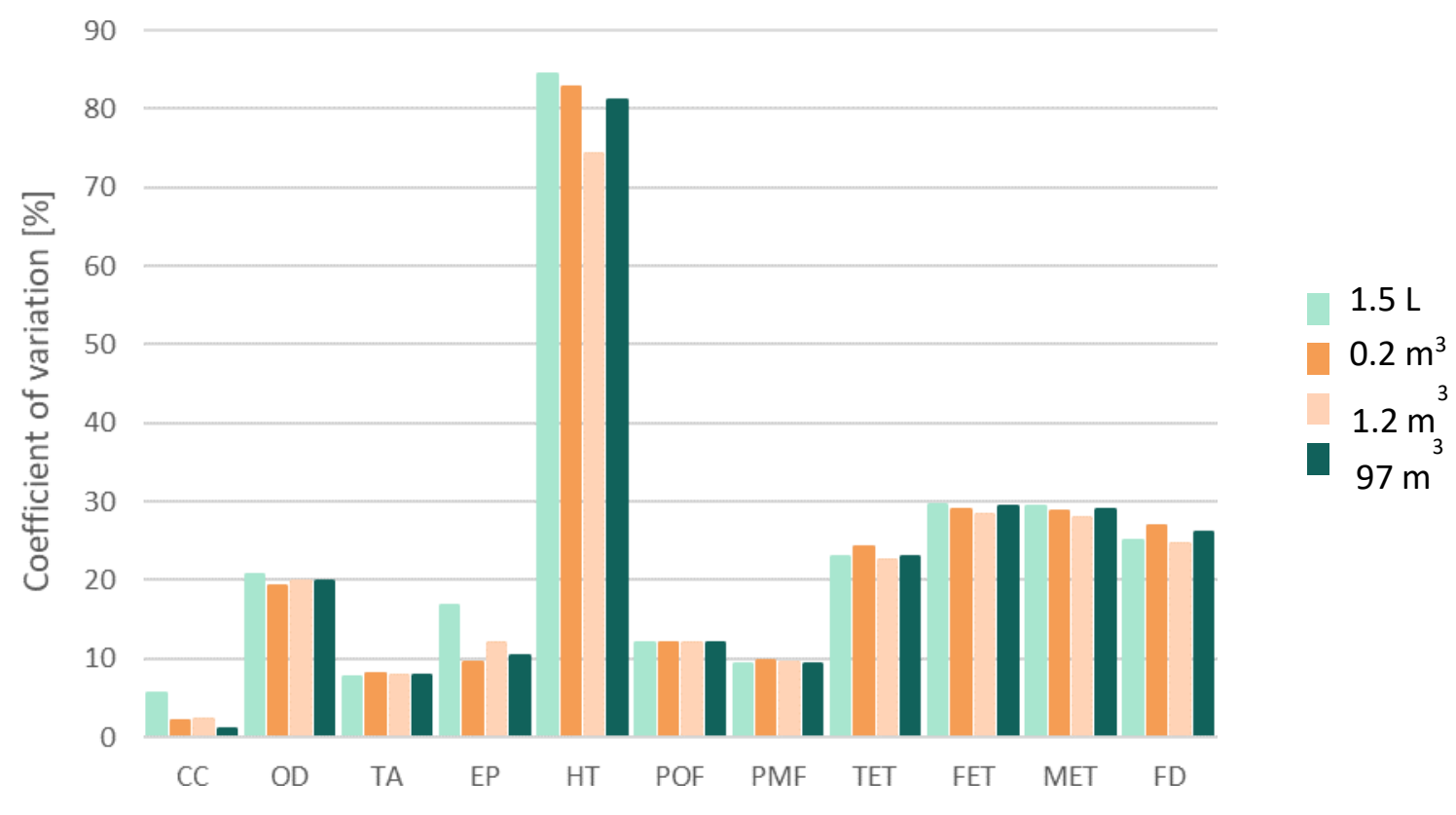

Figure 4 

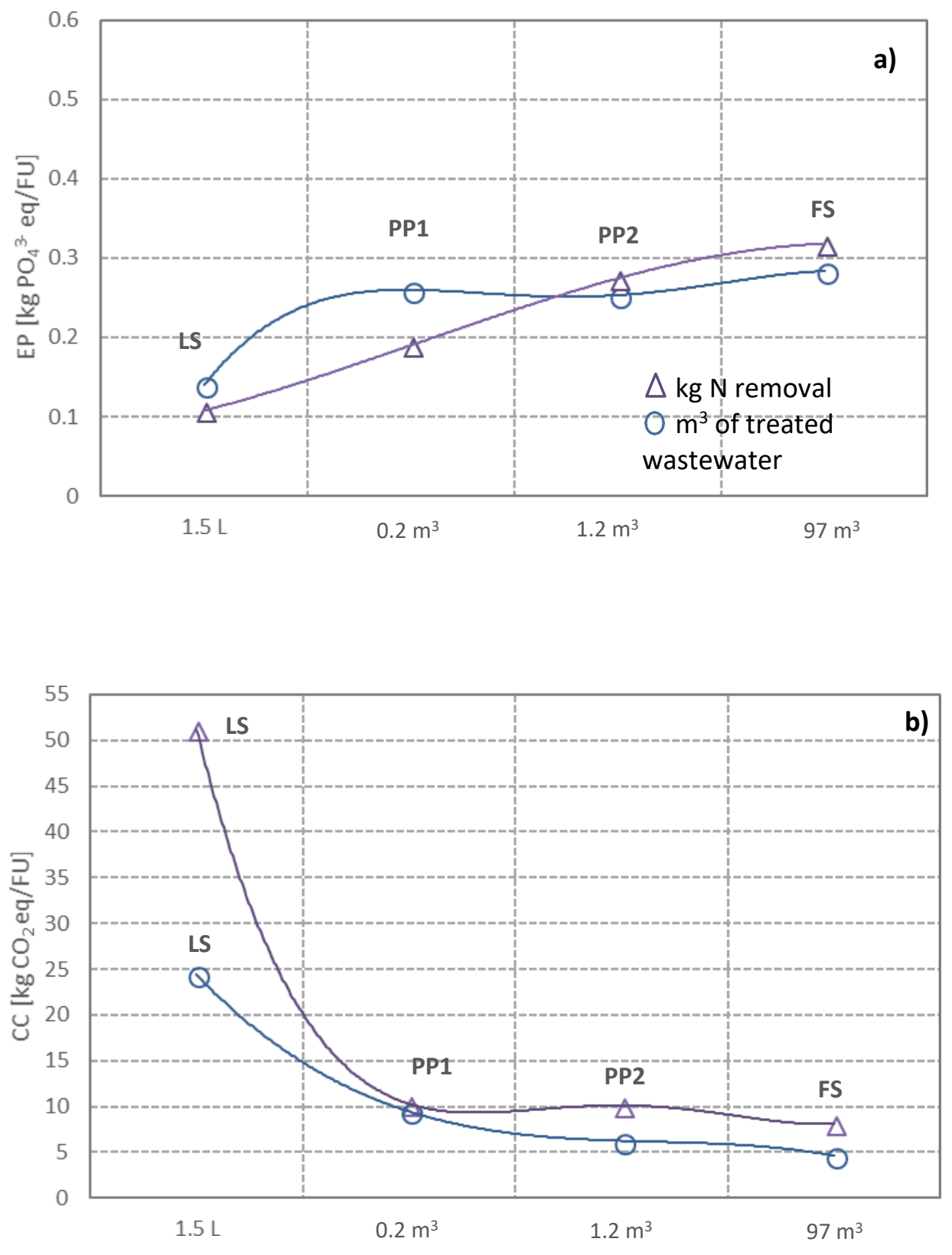

Figure 5 
Table 1. Description of the technical characteristics and operational conditions corresponding to the different evaluated reactors resulting in the ELAN ${ }^{\circledR}$ technology development (Morales et al., 2015a; Vázquez-Padín et al., 2009)

\begin{tabular}{|c|c|c|c|c|}
\hline & LS* & PP1 & PP2 & FS \\
\hline Material & Glass & Stainless Steel & Glass-Fiber & Reinforced concrete \\
\hline $\begin{array}{l}\text { Volume } \\
\text { Installed Power }\end{array}$ & $1.5 \mathrm{~L}$ & $0.2 \mathrm{~m}^{3}$ & $1.2 \mathrm{~m}^{3}$ & $115 \mathrm{~m}^{3}$ (97 useful volume) \\
\hline$\left(\mathrm{kW} / \mathrm{m}^{3}\right)$ & 140 & 16.5 & 0.90 & 0.16 \\
\hline $\mathrm{T}\left({ }^{\circ} \mathrm{C}\right)$ & $18-24$ & $24-30$ & $24-30$ & $24-30$ \\
\hline pH & 7.7 & 7.4 & 7.7 & 7.5 \\
\hline VER (\%) & 25 & 25 & 21 & 44 \\
\hline HRT (d) & 0.5 & 1 & 1.2 & 0.75 \\
\hline $\mathrm{DO}(\mathrm{mg} \mathrm{O} / \mathrm{L})$ & 0.5 & 1.5 & 0.5 & $0.2-0.5$ \\
\hline$N L R\left(k g ~ N / m^{3} \cdot d\right)$ & 0.25 & 0.77 & 0.45 & 0.46 \\
\hline
\end{tabular}

*LS: Laboratory Scale; PP: Pilot Plant; FS: Full Scale 
Table 2. Life Cycle Inventory of LS (1.5 L) per $1 \mathrm{~m}^{3}$ of treated wastewater. Adapted from Vazquez-Padín et al., (2009)

\begin{tabular}{|c|c|c|c|}
\hline \multicolumn{2}{|c|}{ INPUTS } & \multicolumn{2}{|l|}{ OUTPUTS } \\
\hline \multicolumn{2}{|c|}{ From the technosphere } & \multicolumn{2}{|c|}{ To the environment } \\
\hline Materials and fuel & & Emissions to water & \\
\hline Water Influent & & $\operatorname{COD}(\mathrm{g})$ & $95.1 \pm 54.1$ \\
\hline $\operatorname{COD}(\mathrm{g})$ & $278.5 \pm 155.6$ & $\mathrm{TN}(\mathrm{g})$ & $51.8 \pm 32.4$ \\
\hline $\mathrm{TN}(\mathrm{g})$ & $233.4 \pm 27.9$ & $\mathrm{NO}_{2}^{-}-\mathrm{N}(\mathrm{g})$ & $0.6 \pm 0.3$ \\
\hline $\mathrm{NH}_{4}^{+}-\mathrm{N}(\mathrm{g})$ & $233.4 \pm 27.9$ & $\mathrm{NO}_{3}^{-}-\mathrm{N}(\mathrm{g})$ & $28.5 \pm 4.6$ \\
\hline $\mathrm{TP}(\mathrm{g})$ & $47 \pm 16.1$ & $\mathrm{NH}_{4}^{+}-\mathrm{N}(\mathrm{g})$ & $25.7 \pm 15.2$ \\
\hline Electricity consump & & $\mathrm{TP}(\mathrm{g})$ & $33 \pm 12.3$ \\
\hline Aeration (kWh) & 60 & Emissions to air & \\
\hline Feeding (kWh) & 4.8 & NO (mg) & 0.001 \\
\hline \multirow[t]{4}{*}{ Emptying (kWh) } & 1 & $\mathrm{~N}_{2} \mathrm{O}(\mathrm{mg})$ & 0.01 \\
\hline & & \multicolumn{2}{|c|}{ To the technosphere } \\
\hline & & Products and co-products & \\
\hline & & Net Sludge production (g TSS) & 0 \\
\hline
\end{tabular}


Table 3. Life Cycle Inventory of PP1 $\left(0.2 \mathrm{~m}^{3}\right)$ per $1 \mathrm{~m}^{3}$ of treated wastewater (data supplied by Aqualia)

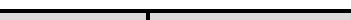

\begin{tabular}{|c|c|c|c|}
\hline \multicolumn{2}{|c|}{ INPUTS } & \multicolumn{2}{|l|}{ OUTPUTS } \\
\hline \multicolumn{2}{|c|}{ From the technosphere } & \multicolumn{2}{|l|}{ To the environment } \\
\hline \multirow{2}{*}{\multicolumn{2}{|c|}{$\begin{array}{l}\text { Materials and fuel } \\
\text { Influent }\end{array}$}} & \multicolumn{2}{|l|}{ Emissions to water } \\
\hline & & TSS (g) & $0.26 \pm 0.19$ \\
\hline TSS (g) & $0.52 \pm 0.44$ & VSS (g) & $0.23 \pm 0.16$ \\
\hline VSS (g) & $0.40 \pm 0.26$ & COD $(g)$ & $214 \pm 29.2$ \\
\hline $\operatorname{COD}(\mathrm{g})$ & $405 \pm 95.3$ & $\mathrm{TN}(\mathrm{g})$ & $202.9 \pm 69.9$ \\
\hline $\mathrm{TN}(\mathrm{g})$ & $1122 \pm 272$ & $\mathrm{NO}_{2}^{-}-\mathrm{N}(\mathrm{g})$ & $1.86 \pm 1.0$ \\
\hline $\mathrm{NO}_{2}^{-}-\mathrm{N}(\mathrm{g})$ & 0 & $\mathrm{NO}_{3}^{-}-\mathrm{N}(\mathrm{g})$ & $53 \pm 25$ \\
\hline $\mathrm{NO}_{3}^{-}-\mathrm{N}(\mathrm{g})$ & 0 & $\mathrm{NH}_{4}^{+}-\mathrm{N}(\mathrm{g})$ & $148 \pm 43.9$ \\
\hline $\mathrm{NH}_{4}^{+}-\mathrm{N}(\mathrm{g})$ & $1122 \pm 272$ & $\mathrm{TP}(\mathrm{g})$ & $36.5 \pm 12.3$ \\
\hline $\mathrm{TP}(\mathrm{g})$ & $48 \pm 16.1$ & \multicolumn{2}{|l|}{ Emissions to air } \\
\hline \multicolumn{2}{|c|}{ Electricity consumption } & $\mathrm{CO}_{2}(\mathrm{mg})$ & 3.79 \\
\hline Aeration (kWh) & 7.37 & $\mathrm{NO}(\mathrm{mg})$ & 0.002 \\
\hline Feeding (kWh) & 1.25 & $\mathrm{~N}_{2} \mathrm{O}(\mathrm{mg})$ & 0.02 \\
\hline \multirow[t]{3}{*}{ Emptying (kWh) } & \multirow[t]{3}{*}{1.25} & \multicolumn{2}{|c|}{ To the technosphere } \\
\hline & & \multicolumn{2}{|l|}{ Products and co-products } \\
\hline & & Net Sludge production (g TSS) & 0 \\
\hline
\end{tabular}


Table 4. Life Cycle Inventory of PP2 $\left(1.2 \mathrm{~m}^{3}\right)$ per $1 \mathrm{~m}^{3}$ of treated wastewater (data supplied by Aqualia company)

\begin{tabular}{|c|c|c|c|}
\hline \multicolumn{2}{|c|}{ INPUTS } & \multicolumn{2}{|l|}{ OUTPUTS } \\
\hline \multicolumn{2}{|c|}{ From the technosphere } & \multicolumn{2}{|l|}{ To the environment } \\
\hline \multirow{2}{*}{\multicolumn{2}{|c|}{$\begin{array}{l}\text { Materials and fuel } \\
\text { Influent }\end{array}$}} & \multicolumn{2}{|l|}{ Emissions to water } \\
\hline & & TSS (g) & $0.24 \pm 0.3$ \\
\hline TSS (g) & $0.42 \pm 0.5$ & VSS (g) & $0.18 \pm 0.2$ \\
\hline VSS (g) & $0.20 \pm 0.1$ & $\operatorname{COD}(\mathrm{g})$ & $152 \pm 104$ \\
\hline $\operatorname{COD}(\mathrm{g})$ & $229 \pm 141$ & $\mathrm{TN}(\mathrm{g})$ & $216.4 \pm 84$ \\
\hline $\mathrm{TN}(\mathrm{g})$ & $808 \pm 162.8$ & $\mathrm{NO}_{2}^{-}-\mathrm{N}(\mathrm{g})$ & $2.40 \pm 3.6$ \\
\hline $\mathrm{NO}_{2}^{-}-\mathrm{N}(\mathrm{g})$ & 0.00 & $\mathrm{NO}_{3}^{-}-\mathrm{N}(\mathrm{g})$ & $75 \pm 38.5$ \\
\hline $\mathrm{NO}_{3}^{-}-\mathrm{N}(\mathrm{g})$ & 0.00 & $\mathrm{NH}_{4}^{+}-\mathrm{N}(\mathrm{g})$ & $139 \pm 83.7$ \\
\hline $\mathrm{NH}_{4}^{+}-\mathrm{N}(\mathrm{g})$ & $808 \pm 162.8$ & $\mathrm{TP}(\mathrm{g})$ & $33.6 \pm 4.5$ \\
\hline $\mathrm{TP}(\mathrm{g})$ & $47 \pm 3.71$ & \multicolumn{2}{|l|}{ Emissions to air } \\
\hline \multicolumn{2}{|l|}{ Electricity consumption } & $\mathrm{CO}_{2}(\mathrm{mg})$ & 5.89 \\
\hline Aeration (kWh) & 5.98 & NO (mg) & 0.001 \\
\hline Feeding (kWh) & 0.26 & $\mathrm{~N}_{2} \mathrm{O}(\mathrm{mg})$ & 0.01 \\
\hline \multirow[t]{3}{*}{ Emptying (kWh) } & \multirow[t]{3}{*}{0.26} & \multicolumn{2}{|l|}{ To the technosphere } \\
\hline & & Products and co-products & \\
\hline & & Net Sludge production (g TSS) & 0 \\
\hline
\end{tabular}


Table 5. Life Cycle Inventory of FS $\left(97 \mathrm{~m}^{3}\right)$ per $1 \mathrm{~m}^{3}$ of treated wastewater (data supplied by Aqualia company)

\begin{tabular}{|c|c|c|c|}
\hline \multicolumn{2}{|c|}{ INPUTS } & \multicolumn{2}{|l|}{ OUTPUTS } \\
\hline \multicolumn{2}{|c|}{ From the technosphere } & \multicolumn{2}{|c|}{ To the environment } \\
\hline \multicolumn{2}{|l|}{ Materials and fuel } & \multicolumn{2}{|l|}{ Emissions to water } \\
\hline \multicolumn{2}{|l|}{ Water Influent } & TSS (g) & $0.3 \pm 0.2$ \\
\hline TSS (g) & $0.4 \pm 0.4$ & VSS (g) & $0.2 \pm 0.1$ \\
\hline VSS (g) & $0.2 \pm 0.4$ & $\operatorname{COD}(\mathrm{g})$ & $171.3 \pm 31$ \\
\hline $\operatorname{COD}(\mathrm{g})$ & $284.1 \pm 55.2$ & $\mathrm{TN}(\mathrm{g})$ & $228.8 \pm 55.8$ \\
\hline $\mathrm{TN}(\mathrm{g})$ & $797.7 \pm 102.8$ & $\mathrm{NO}_{2}^{-}-\mathrm{N}(\mathrm{g})$ & $5.9 \pm 6.1$ \\
\hline $\mathrm{NO}_{2}^{-}-\mathrm{N}(\mathrm{g})$ & 0.00 & $\mathrm{NO}_{3}^{-}-\mathrm{N}(\mathrm{g})$ & $93.1 \pm 18.3$ \\
\hline $\mathrm{NO}_{3}^{-}-\mathrm{N}(\mathrm{g})$ & 0.00 & $\mathrm{NH}_{4}^{+}-\mathrm{N}(\mathrm{g})$ & $109.7 \pm 23.2$ \\
\hline $\mathrm{NH}_{4}^{+}-\mathrm{N}(\mathrm{g})$ & $569.1 \pm 20.4$ & $\mathrm{TP}(\mathrm{g})$ & $44.8 \pm 17.6$ \\
\hline $\mathrm{TP}(\mathrm{g})$ & $61.2 \pm 34.9$ & \multicolumn{2}{|l|}{ Emissions to air } \\
\hline \multicolumn{2}{|c|}{ Electricity consumption } & $\mathrm{CO}_{2}(\mathrm{mg})$ & 6.1 \\
\hline Aeration (kWh) & 2.2 & $\mathrm{NO}(\mathrm{mg})$ & 0.001 \\
\hline Feeding (kWh) & 0.1 & $\mathrm{~N}_{2} \mathrm{O}(\mathrm{mg})$ & 0.01 \\
\hline \multirow[t]{3}{*}{ Emptying (kWh) } & \multirow[t]{3}{*}{0.01} & \multicolumn{2}{|c|}{ To the technosphere } \\
\hline & & \multicolumn{2}{|l|}{ Products and co-products } \\
\hline & & Net Sludge production (g TSS) & 0 \\
\hline
\end{tabular}


Table 6. Environmental results of the different reactors, resulting in the ELAN ${ }^{\circledR}$ process, for the impact categories under assesment. FU: $1 \mathrm{~m}^{3}$ of treated wastewater. Acronyms: LS: $1.5 \mathrm{~L}, \mathrm{PP} 1: 0.2 \mathrm{~m}^{3}$, PP2: $1.2 \mathrm{~m}^{3}$ and FS: $97 \mathrm{~m}^{3}$

\begin{tabular}{|c|c|c|c|c|}
\hline Impact Categories & LS & PP1 & PP2 & FS \\
\hline $\begin{array}{l}\text { Climate change (CC) } \\
\quad\left(\mathrm{kg} \mathrm{CO}{ }_{2} \mathrm{eq}\right)\end{array}$ & 24.39 & 9.46 & 6.24 & 4.62 \\
\hline $\begin{array}{l}\text { Ozone depletion (OD) } \\
\quad(\text { kg CFC-11 eq) }\end{array}$ & $3.02 \cdot 10^{-6}$ & $4.51 \cdot 10^{-7}$ & $2.97 \cdot 10^{-7}$ & $1.02 \cdot 10^{-7}$ \\
\hline $\begin{array}{c}\text { Terrestrial acidification } \\
\text { (TA) } \\
\left(\mathrm{kg} \mathrm{SO}_{2} \text { eq }\right)\end{array}$ & 0.12 & 0.02 & 0.01 & $4.17 \cdot 10^{-3}$ \\
\hline $\begin{array}{l}\text { Eutrophication (EP) } \\
\qquad\left(\mathrm{kg} \mathrm{PO}_{4}{ }^{3-} \text { eq) }\right.\end{array}$ & 0.14 & 0.26 & 0.25 & 0.28 \\
\hline $\begin{array}{l}\text { Human toxicity (HT) } \\
\qquad(\mathrm{kg} \mathrm{1,4-DCB} \mathrm{eq)}\end{array}$ & 5.13 & 0.77 & 0.50 & 0.17 \\
\hline $\begin{array}{c}\text { Photochemical } \\
\text { Oxidation Formation } \\
\text { (POF) } \\
\text { (kg NMVOC) }\end{array}$ & 0.06 & 0.01 & 0.01 & $2.11 \cdot 10^{-3}$ \\
\hline $\begin{array}{l}\text { Particulate Matter } \\
\text { Formation (PMF) } \\
\quad\left(\mathrm{kg} \mathrm{PM}_{10} \mathrm{eq}\right)\end{array}$ & 0.04 & 0.01 & $4.30 \cdot 10^{-3}$ & $1.48 \cdot 10^{-3}$ \\
\hline $\begin{array}{c}\text { Terrestrial Ecotoxicity } \\
\text { (TET) } \\
\text { kg 1,4-DCB eq) }\end{array}$ & $5.33 \cdot 10^{-4}$ & $7.97 \cdot 10^{-5}$ & $5.25 \cdot 10^{-5}$ & $1.81 \cdot 10^{-5}$ \\
\hline $\begin{array}{c}\text { Freshwater Ecotoxicity } \\
\text { (FET) } \\
(\mathrm{kg} \mathrm{1,4-DCB} \mathrm{eq)}\end{array}$ & 0.38 & 0.06 & 0.04 & 0.01 \\
\hline $\begin{array}{c}\text { Marine Ecotoxicity } \\
\text { (MET) } \\
\text { (kg 1,4-DCB eq) }\end{array}$ & 0.34 & 0.06 & 0.04 & 0.01 \\
\hline $\begin{array}{l}\text { Water Depletion (WD) } \\
\qquad\left(\mathrm{m}^{3}\right)\end{array}$ & 0.19 & 0.03 & 0.02 & 0.01 \\
\hline $\begin{array}{l}\text { Fossil Depletion (FD) } \\
\quad(\mathrm{kg} \text { oil eq) }\end{array}$ & 5.39 & 0.80 & 0.53 & 0.18 \\
\hline
\end{tabular}




\title{
Bottom-up approach in the assessment of environmental impacts and costs of an innovative anammox-based process for nitrogen removal
}

\author{
Andrea Ariass,", Iana Salimª, Alba Pedrouso ${ }^{a}$, Nicolás Morales ${ }^{\mathrm{b}}$, Anuska Mosquera- \\ Corral $^{\mathrm{a}}$, José Ramón Vázquez-Padín ${ }^{\mathrm{b}}$, Frank Rogalla ${ }^{\mathrm{b}}$, Gumersindo Feijoo ${ }^{\mathrm{a}}$, María Teresa \\ Moreira $^{\mathrm{a}}$ \\ ${ }^{a}$ Department of Chemical Engineering, School of Enginering, Universidade de Santiago de Compostela, \\ E-15782, Santiago de Compostela, Galicia, Spain \\ ${ }^{\mathrm{b}}$ Aqualia, Guillarei WWTP, Camino de la Veiga s/n, E-36720, Tui, Spain \\ * Corresponding author. E-mail: andrea16_verin@hotmail.com
}




\section{Abstract}

In recent decades, the wastewater treatment sector has undergone a shift to adapt to increasing discharge limits. In addressing the evaluation of innovative technologies, it is necessary to determine the scale at which reliable and representative values of environmental impacts and costs can be obtained, ensuring that the system under assessment follows the direction of eco-efficiency.

This study has evaluated the environmental and economic indicators of an autotrophic nitrogen removal technology $\left(\mathrm{ELAN}^{\circledR}\right)$ from laboratory conception $(1.5 \mathrm{~L})$ to full scale (2 units of $115 \mathrm{~m}^{3}$ ) using the Life Cycle Assessment (LCA) methodology. Indirect emissions related to electricity consumption are the main contributor in all impact categories except eutrophication. Electricity consumption referred to the functional unit ( $1 \mathrm{~m}^{3}$ of treated wastewater) decreases as the scale increases. The rationale behind this can be explained, among other reasons, by the low energy efficiency of small-scale equipment (pumps and aerators). Accordingly, a value of approximately $25 \mathrm{~kg} \mathrm{CO}_{2 \text { eq }}$ per $\mathrm{m}^{3}$ of treated water is determined for laboratory scale, compared to only $5 \mathrm{~kg} \mathrm{CO}$ 2eq per $\mathrm{m}^{3}$ at full-scale. When it comes to assessing the reliability of data, a pilot scale system of $0.2 \mathrm{~m}^{3}$ allowed to perform a trustworthy estimation of environmental indicators, which were validated at full-scale. In terms of operational costs, the scale of approximately $1 \mathrm{~m}^{3}$ provided a more accurate estimate of the costs associated with energy consumption.

Keywords: partial nitritation-anammox; scale-up analysis; sustainable wastewater 


\section{Nomenclature}

Anammox

AOB

CAS

CC

CML

COD

DO

ELAN $^{\circledR}$

EP

FD

FET

FS

FU

HRT

HT

LCA

LCI

LS

MET

NOB

OD

OLAND

PMF

PN-AMX

POF

PP1

PP2

SBR

SCENA

TA

TET

VER

WD
Anaerobic Ammonium Oxidation

Ammonium-Oxidizing Bacteria

Conventional Activated Sludge System

Climate Change

Centre of Environmental Science of Leiden University

Chemical Oxygen Demand

Dissolved Oxygen

Autotrophic Nitrogen Removal, in Spanish

(ELiminación Autótrofa de Nitrógeno)

Eutrophication Potential

Fossil Depletion

Freshwater EcoToxicity

Full Scale

Functional Unit

Hydraulic Retention Time

Human Toxicity

Life Cycle Assessment

Life Cycle Inventory

Laboratory Scale

Marine EcoToxicity

Nitrite-Oxidizing Bacteria

Ozone Depletion

Oxygen Limited Autotrophic Nitrification-Denitrification

Particulate Matter Formation

Partial Nitritation-AnaMmoX

Photochemical Oxidation Formation

Pilot Plant 1

Pilot Plant 2

Sequencing Batch Reactor

Short Cut Enhanced Nutrient Abatement

Terrestrial Acidification

Terrestrial EcoToxicity

Volume Exchange Ratio

Water Depletion 
1

2

3

4

6

9 
1
2

\section{Introduction}

In the design of new processes and products, there is a growing demand to label them as sustainable from the earliest stages of their conception and development. Traditionally, the evolution of an innovative technology, from its conception to its implementation in the market, consists in overcoming a series of successive stages of development, where performance and operational conditions vary according to scale, making them comparable to conventional technologies. When introducing the environmental and economic perspectives, it is necessary to evaluate the scale level that allows reliable and representative values of environmental impacts and costs to be obtained, ensuring that the emerging technology is moving in the direction of ecoefficiency. This stage is critical, as it will mean the "abandonment" or "scaling up" of R\&D activities to large-scale installation.

In the context of wastewater treatment, reducing the nitrogen load in the treated effluents is one of the main objectives to avoid excessive growth of algae in watercourses (eutrophication), toxicity by ammonia and decrease of dissolved oxygen, negatively affecting aquatic fauna and flora ( $\mathrm{Li}$ and Brett, 2012). In accordance with the European Water Framework Directive (2000/60/EC), a nitrogen discharge limit of 10 - 15 mg N/L applies for European wastewater treatment plants (WWTPs) in sensitive areas, provided that $70-80 \%$ of the total nitrogen in the influent is removed. This increased legislation restriction leads to the development of novel treatment technologies that need to be validated from an environmental and economic point of view (Machado et al., 2009; Wang et al., 2012). Several authors highlighted the balance between nitrogen removal and energy demand, which may lead to an increase in indirect greenhouse gas emissions depending on the complexity of the treatment scheme (Foley 
1 et al., 2010a; Lederer and Rechberger, 2010; Rodriguez-Garcia et al., 2011; Vidal et al., 2 2002).

Conventional nitrogen removal from wastewater is based on the biological nitrification-denitrification processes. Beyond the requirements of aeration and depending on the $\mathrm{COD} / \mathrm{N}$ ratio of the wastewater, the addition of an external carbon source may be required, which implies operational costs between $2.85-3.64 € / \mathrm{kg} \mathrm{N}$ removed. Furthermore, conventional technologies require extensive land use, increasing capital costs (Renzi et al., 2015).

The combination of partial nitritation-anammox (anaerobic ammonium oxidation) processes (Jetten et al., 2002; Mosquera-Corral et al., 2005) or partial nitrificationdenitrification (Renzi et al., 2015) are interesting alternatives to the conventional nitrification-denitrification processes. In recent years, new innovative technologies have been developed to incorporate these processes such as SCENA (Short Cut Enhanced Nutrient Abatement) (Renzi et al., 2015), OLAND (Oxygen Limited Autotrophic Nitrification-Denitrification) (Kuai and Verstraete, 1998) and ELAN ${ }^{\circledR}$ (autotrophic nitrogen removal in Spanish "ELiminación Autótrofa de Nitrógeno”) (Vázquez-Padín et al., 2014a). These technologies are applied for the treatment of the supernatant from the anaerobic sludge digesters which are nutrient rich side streams in the WWTP (VázquezPadín et al., 2014a, Longo et al. 2017). When ELAN ${ }^{\circledR}$ process is used for nitrogen removal, it can reduce oxygen requirements to $1.83 \mathrm{~kg} \mathrm{O}_{2} / \mathrm{kg} \quad \mathrm{N}_{\text {removed, with no }}$ consumption of organic matter and an outstandingly low biomass yield of $0.12 \mathrm{~kg}$ $\mathrm{VSS} / \mathrm{kg} \mathrm{N} \mathrm{N}_{\text {removed, }}$ compared to the remarkably higher values of $3.18 \mathrm{~kg} \mathrm{O}_{2} / \mathrm{kg} \mathrm{N}_{\text {removed, }}$, $4.9 \mathrm{~kg} \mathrm{COD} / \mathrm{kg} \mathrm{N}_{\text {removed }}$ and $2.11 \mathrm{~kg} \mathrm{VSS} / \mathrm{kg} \quad \mathrm{N}_{\text {removed }}$ in the case of nitrification/denitrification process (Vázquez-Padín et al., 2014a). 
1 With the aim of assessing the sustainability of water treatment technologies, the

2 Life Cycle Assessment (LCA) methodology arises as a good alternative because it

3 allows quantifying the potential environmental impacts throughout the entire cycle of a

4 product or process (ISO, 2006). This methodology has been widely used to evaluate the

5 efficiency of WWTPs or to study different treatment alternatives (Foley et al., 2010b;

$6 \quad$ Hospido et al., 2004; Lorenzo-Toja et al., 2016a). Beyond complying with water

7 discharge regulations, it must taken into account that among the different treatment

8 schemes, some might be considered advantages when applied to speficic cases, not only

9 considering environmental but also economic perspectives (Longo et al., 2017; LorenzoToja et al., 2016b; Rodriguez-Garcia et al., 2011). another has discredited the concept in some areas (Heijungs et al., 2010; Weidema, 2003). One of these weaknesses is attributed to the collection and validity of data required for the life cycle inventory (LCI). This stage is critical as it will compute the consumption of raw materials, chemicals, water and energy for each stage of the process, as well as emissions to air, water and soil (Finnveden, 2000; Lorenzo-Toja et al., 2016; Tillman, 2000). When the inventory data are executed from reliable data, it is possible to obtain accurate environmental impacts. This includes the need to make judgements based on the figures collected to assess the likely significance of the various impacts (Reap et al., 2008). However, uncertainty arises regarding the scale of development required. Furthermore, when the aim is to evaluate a technology under development, this drawback is even more important. The definition of the scale of development required, which provides reliable data for LCA, is therefore relevant to ensure the successful implementation of a bottom-up approach. 
1 The main objective of this study is to define the scale for which data collection in

2 the LCA methodology provide a reliable evaluation of a technology under development.

3 In particular, the assessment of an innovative wastewater treatment technology for $4 \quad$ nitrogen removal $\left(\mathrm{ELAN}^{\circledR}\right)$ from lab conception to full-scale was conducted. 


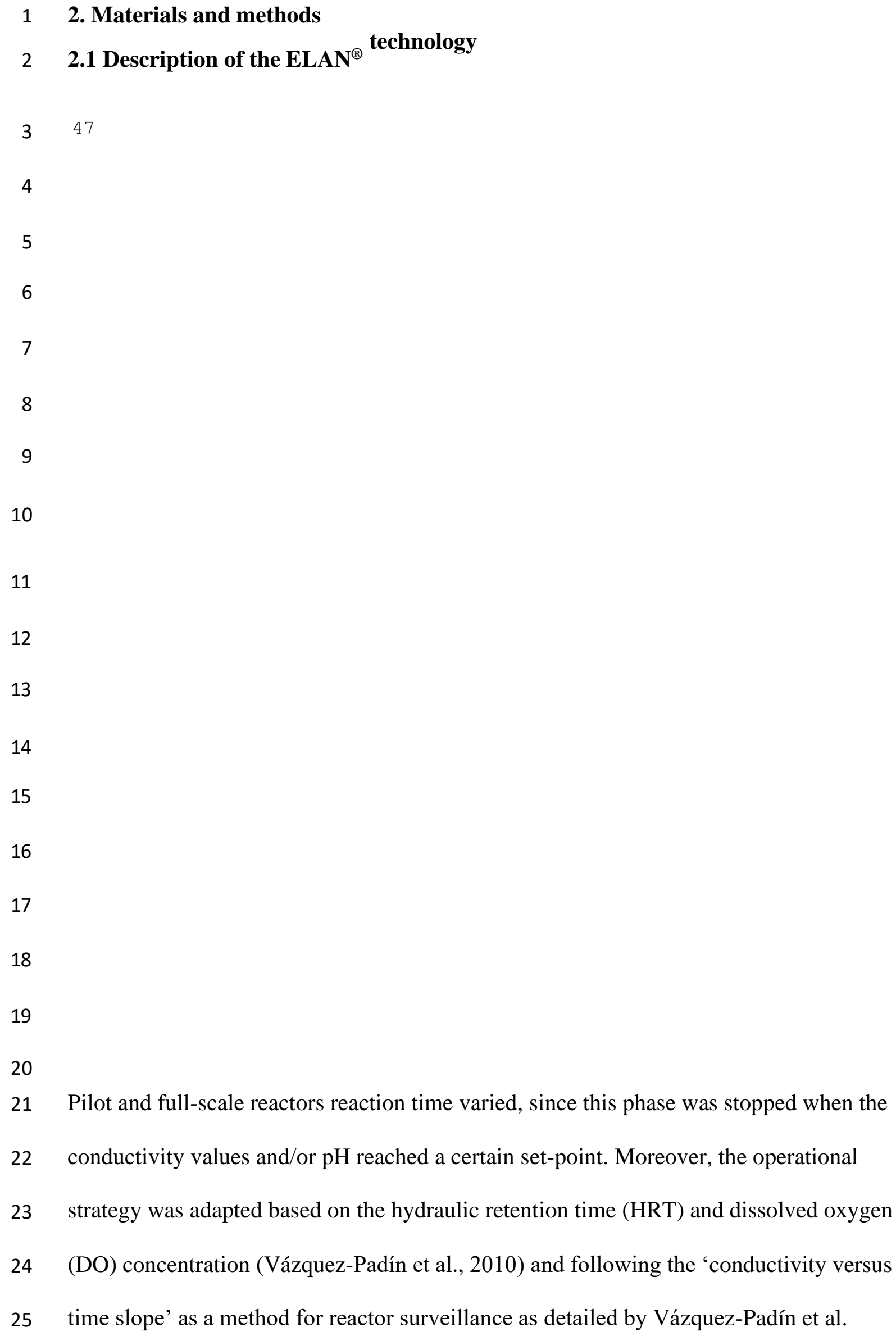

\subsection{Description of the ELAN ${ }^{\circledR}$ technology}

3

47

4

5

6

7

8

9

10

11

12

13

14

15

16

17

18

19

20

21 Pilot and full-scale reactors reaction time varied, since this phase was stopped when the

22 conductivity values and/or $\mathrm{pH}$ reached a certain set-point. Moreover, the operational

23 strategy was adapted based on the hydraulic retention time (HRT) and dissolved oxygen

24 (DO) concentration (Vázquez-Padín et al., 2010) and following the "conductivity versus

25 time slope' as a method for reactor surveillance as detailed by Vázquez-Padín et al. 
T 1 artialateritationanhathamoxox (PN-AMX) processes in the same unit (Vázquez-Padín et

$\mathrm{h}$

e

E

L

A

$\mathrm{N}$

$(8$

$\mathrm{t}$

e

c

h

$\mathrm{n}$

o

o

g

y

c

o

$\mathrm{m}_{4}^{48}$

50

b1

al., 2010). In the partial nitritation process, the ammonium oxidizing bacteria (AOB) oxidize ammonium to nitrite, while the oxidation of nitrite to nitrate by the nitrite oxidizing bacteria (NOB) should be avoided (Vazquez-Padin et al., 2009). The anammox bacteria are capable of oxidizing ammonium to nitrogen gas using nitrite as electron acceptor, without the need of organic matter or oxygen (Dapena-Mora et al., 2004). Thus, in the $\mathrm{ELAN}^{\circledR}$ technology, nitrogen is autotrophically removed.

ELAN $^{\circledR}$ technology was developed in a sequencing batch reactor (SBR) with granular sludge (Figure 1). The establishment of aerobic and anoxic zones within the granule, depending on oxygen depth penetration, allow the operation in a single step (Morales 2015a). Four different reactor sizes (from $1.5 \mathrm{~L}$ to $115 \mathrm{~m}^{3}$ ) were analysed in this study (Table 1): Laboratory Scale (LS), Pilot Plant 1 (PP1), Pilot Plant 2 (PP2) and Full-scale (FS). The SBR operational cycle comprised the following stages: feeding, aerobic reaction, settling and withdrawal (Figure 1). The LS reactor, operated under the approach of the ELAN ${ }^{\circledR}$ process, operated at fixed-cycle duration of $3 \mathrm{~h}$ throughout the whole operational period cycles duration. The volume exchange ratio (VER), or ratio between the volume of effluent discharged and the volume of the reactor, was $25 \%$.

\footnotetext{
21 Pilot and full-scale reactors reaction time varied, since this phase was stopped when the conductivity values and/or $\mathrm{pH}$ reached a certain set-point. Moreover, the operational strategy was adapted based on the hydraulic retention time (HRT) and dissolved oxygen (DO) concentration (Vázquez-Padín et al., 2010) and following the 'conductivity versus time slope' as a method for reactor surveillance as detailed by Vázquez-Padín et al.
} 
1 (2014a). For this purpose the reactor is provided with a set of probes (conductivity,

$2 \mathrm{pH}, \ldots)$ connected to a control system. In this study, an average of cycle length was

3 considered, $6 \mathrm{~h}$ for PP1 and PP2 reactors, and $8 \mathrm{~h}$ for the FS reactor. The VER values of

4 each reactor was: $25 \%$ for PP1, $21 \%$ for PP2 and finally $44 \%$ for FS.

\section{$>$ FIGURE $1<$}

$>$ TABLE $1<$

\subsection{Approach for data collection in LCA methodology}

The LCA methodology according to a gate-to-gate approach was applied, following the ISO 14040 standard. The main impacts of WWTPs occur in the operational phase (Lundie et al., 2004). The construction phase was not taken into account because the infrastructure of each reactor is made up of different materials depending on the scale, availability and cost, which determines that emissions from this phase between small and full-scale are not comparable (Table 1). Similarly, the impacts associated with the decommissioning phase may be considered negligible (Foley et al., 2010b; Lorenzo- Toja et al., 2016b). Therefore, only the environmental impacts associated with the operational phase of each reactor were assessed in this study.

The functional unit (FU) should reflect the main function of the analysed system and be consistent with the goal and scope of the study (ISO, 2006). The most common FU used in LCA studies of WWTPs are the following: population equivalent (Gallego et al., 2008; Machado et al., 2007), kg N removed (Hauck et al., 2016; RodriguezGarcia et al., 2011) or $\mathrm{m}$ of treated wastewater (Hospido et al., 2012; Pasqualino et al., 2011). Under the approach of different scales, population equivalent does not apply in the LS, PP1 or PP2 scenarios. Consequently, one cubic meter (1 $\mathrm{m}^{3}$ ) of treated wastewater was selected as FU, which can be a straightforward solution when 
1 comparing different scales of operation. Moreover, a sensitivity analysis was performed

2 considering a FU of $\mathrm{kg} \mathrm{N}$ removed for benchmarking of the environmental outcomes.

The LCI has been developed with primary data from the laboratory scale, two pilot plant reactors and full- scale reactor, obtained during the different stages of development of the $\mathrm{ELAN}^{\circledR}$ process (Tables 2, 3, 4 and 5, respectively). Laboratory scale reactor was operated in the University of Santiago de Compostela, while pilots and full scale ELAN ${ }^{\circledR}$ reactors were operated in the Guillarei WWTP (Northwest of Spain), where the pilots and full scale ELAN ${ }^{\circledR}$ reactors are operated by Aqualia, since 2012 and 2015, respectively.

$>$ TABLE $2<$

$>$ TABLE 3<

$>$ TABLE $4<$

$>$ TABLE $5<$

Emissions to air (NO, $\mathrm{N}_{2} \mathrm{O}$ and $\mathrm{CO}_{2}$ ) were calculated according to Kampschreur et al. (2008) and Morales et al. (2015a). The power consumption of the reactors has been calculated according to the operating time and power of the pumps used. The Ecoinvent v3.2 database for the Spanish electricity production and import/export mix process was updated for 2016 with data from the annual report of Red Eléctrica Española (2016). In Spain, WWTPs use medium-voltage electricity (Lorenzo-Toja et al., 2016); thus, the high voltage electricity was converted to medium voltage, considering emissions to air and losses in transport (Dones et al., 2007).

\subsection{Assessment methodology and impact categories}

SimaPro v.8.2 software was used for the impact assessment. Two different assessment methods were used to provide the most characteristic environmental impacts 
1 of WWTPs (Rodriguez-Garcia et al., 2011). Eutrophication potential (EP) was

2 calculated using the CML method (Guinée, 2002). Climate change (CC), ozone

3 depletion (OD), terrestrial acidification (TA), photochemical oxidation formation

4 (POF), particulate matter formation (PMF), human toxicity (HT), terrestrial ecotoxicity

5 (TET), freshwater ecotoxicity (FET), marine ecotoxicity (MET), water depletion (WD)

6 and fossil depletion (FD) were calculated with the ReCiPe midpoint method (Goedkoop

7 et al., 2009).

The rationale behind the selection of two methodologies is based on their different

9 approach to quantify for the impact attributed to the chemical oxygen demand (COD).

Whereas COD does not have a characterisation factor in the ReCiPe (Goedkoop et al., 2009), which leads to an underestimation of impacts, the CML method takes into account the impact of COD on the eutrophication impact category (Guinée, 2002). Thus, the CML method is more appropriate to assess the EP impact in the case of WWTPs since COD is a limiting discharge parameter according to legislation (91/271/CEE).

\subsection{Economic sustainability indicator}

The operational costs related to electricity consumption were selected as economic indicator. The amount of sludge generation in the $\mathrm{ELAN}^{\circledR}$ process is considered negligible (Vazquez Padin et al., 2014b), so the cost of sludge is not taken into account

in this study. In addition, since there is no addition of chemicals during the operation of the reactors, the costs associated with chemical consumption are not considered (Vazquez Padin et al., 2014b).

\section{5 . Uncertainty analysis methodology}


1 The management of WWTPs faces variable operating conditions, flows and

2 composition of the flow to be treated, which can strongly influence the results of the

3 LCA studies (Yoshida et al., 2014). The most likely factors of uncertainty are: i)

4 uncertainty of parameters such as calibration of measurement equipment, human errors

5 or mismatches between different measurements of the same parameter and ii)

6 uncertainty associated to the background processes including in the databases, such as

7 electricity consumption (Huijbregts, 2002). In this study, the Monte Carlo uncertainty

8 method included in the SimaPro 8.2 software was applied. In this method, four types of

9 probability can be considered: uniform, triangular, normal and lognormal (Fantin et al.,

10 2015). For the background parameters (Ecoinvent v3.2 database), the lognormal is the

11 default selected probability distribution, while for the water characterization parameters

12 the normal distribution was selected. According to other studies (Guo and Murphy, 2012;

13 Longo et al., 2017), the Monte Carlo analysis was performed with 1,000 iterations at a 95\% significance level. 


\section{3. Results}

\section{3.1. Environmental and economic profiles}

3

4

5 the different environmental categories is the energy consumption, mainly associated with

6 the aeration process (Tables 2 to 5), which has a drastic effect when considering the scale

7 of the reactor, since at small scale (corresponding to the early stages of technology

8 development), the equipment used (pumps and aerators) is overdimensioned, that render

9 into larger electricity consumption, and therefore, leading to much higher impacts (Figure 2).

\section{$>$ TABLE $6<$}

As the scale increases, energy consumption is reduced. The reduction from PP1 to FS is not very high, approximately $9 \%$. This reduction is more important when the scale is increased from LS to FS (75\%), which is attributed to the overdimensioning of pumps and aerators used at small scale.

This reduction of energy translates into a lower impact in the different impact categories which are energy dependent (Table 6). The impact reduction is the same for all categories (about $75 \%$ from LS to FS) except for the climate change category.

In the climate change category, the impact is provoked by the non biogenic $\mathrm{CO}_{2}$ emited from fuel fossil combustion. The emissions are reduced as the scale increases from $55 \%$ in LS to $10 \%$ for FS (Figure $2 \mathrm{a}$ ). In PP1, PP2 and FS, the emissions values are very similar, with impact reductions from 10 to $20 \%$ (Figure 2a). 
1 Considering that the final objective of a WWTP is to reduce the organic load and

2 eutrophication impact, one of the environmental categories that arises as essential is the eutrophication potential. This category does not depend on energy consumption, and compared to the other impact categories, the values show an opposite trend and change significantly among configurations (Figure 2b). The LS has lower eutrophication potential (15\%) due to the composition of the wastewater fed into the reactor with a lower concentration of N, about $77 \%$ in comparison to the FS (Vazquez-Padin et al., 2009). For this reason, the obtained result for LS in this EP category is not realistic enough to be compared with that from the other pilot or full-scale reactors. For the PP1, PP2 and FS systems, the impact is very similar approximately of $30 \%$. These reactors treated the reject water from sludge digester in the Guillarei municipal WWTP and the removal of compounds like COD, TN (inorganic and organic) or phosphorus that generate impact in this category was considered for the calculation (Table 2 to Table 5). Thus, the comparison in the eutrophication category is viable only between the pilot and the fullscale reactors. As the ELAN $^{\circledR}$ process accomplishes nitrogen removal it would be interesting to benchmark the eutrophication it "reduces" in comparison with a conventional system operated for the same purpose, or just the effect, on the secondary treatment of the WWTP where the reject water from the sludge anaerobic digester is recycled, but it is beyond the scope of this study.

The effect on the human toxicity category is associated with the indirect emissions from the electricity production. In Figure 2c, it can be seen that LS has the major impact and for the PP1, PP2 and FS, this impact decreases with size. The reduction from LS to PP1 is $66 \%$ whereas HT impact is further decreased to $75 \%$ in FS.

Since there is no chemical consumption and the amount of sludge produced can be considered negligible (Vazquez Padin et al., 2014a), only operational costs related to 
1 electricity consumption in the reactors evaluated for ELAN® process development were analysed for the economic assessment. The electricity costs are represented in Figure 3 per one cubic meter of treated wastewater $\left(€ / \mathrm{m}^{3}\right)$, ranging from $8 € / \mathrm{m}^{3}(\mathrm{LS})$ to $0.3 € / \mathrm{m}^{3}$ (FS). These values are related to the climate change impacts of each reactor.

\section{$>$ FIGURE 3<}

\subsection{Uncertainty analysis results}

The statistical parameters of the Monte Carlo analysis for each reactor are shown in the supplementary material (Tables S.1 to S.4). In these tables, the mean values, median, standard deviation, coefficient of variation and standard error of the mean for each reactor are calculated. The uncertainty for the different environmental categories, can be represented in terms of the coefficient of variation defined as the relationship between the variability of the data concerning the standard deviation (Figure 4). The uncertainty is independent of the scale of the installation, as the same behaviour was found for all categories. Furthermore uncertainty was less than $30 \%$ for all categories with the exception of the "Human toxicity" category. The value of the environmental impact derived from this category depends to a large extent on the electricity production process considered and, more specifically, on the effect of the heavy metals associated with the process. The electricity consumption of the different treatment systems was primary data, but the profile and processes of electricity generation are secondary (obtained from the Ecoinvent v.3.2 database). The Ecoinvent processes tend to have a high uncertainty that affects the final results and for this reason the uncertainty is higher in this category from $74 \%$ in PP2 to $85 \%$ in LS. Consequently, the data obtained for the environmental impact study of the ELAN ${ }^{\circledR}$ technology according to the scale of the reactor can be considered representative. 
2

3

4

\section{Discussion}

Currently, extrapolation of laboratory scale emissions to industrial facilities can only be estimated, not measured. However, estimation using bottom-up techniques (e.g., using scale factors) can produce overestimated impacts. By selecting an appropriate scale of development, we can produce inventories that are accurate in the sense of being neither over nor underestimated to the extent possible, and where uncertainties are reduced. When LCA is used to support decision making, confidence in LCI data needs to be assured. In ideal circumstances, inventory data are validated and uncertainty can be quantified. Obtaining reliable inventory data, clearly described and accurately reported, is not easy and can seriously hamper the implementation of LCA. The use of published inventory databases may be useful only for background processes, but not especially when it is an innovative technology in its early stages of development. This will help to understand the magnitude of the environmental impacts and are a key element in reporting on progress and monitoring changes associated with improvement actions towards objectives.

\subsection{Categories dependent on electricity consumption}

In this study, the indirect emissions caused by energy consumption are presented in all categories except eutrophication. It should be noted that electricity emissions depend

on the electricity mix of each country. In Spain, electricity production is represented by $59.2 \%$ of non-renewable energy and $40.8 \%$ of renewable energy (REE, 2016).

As indicated in section 2.1, the ELAN ${ }^{\circledR}$ technology includes a number of energyconsuming operational stages (feeding, aeration and withdrawal) (Figure 1). Energy consumption should be optimised, as it is a parameter that directly affects climate 
1 change and the major contributor of the different environmental categories. Electricity

2 consumption decreases as the scale increases (FS $<\mathrm{PP} 2<\mathrm{PP} 1<\mathrm{LS})$ (Figure 2).

3 Consequently, the impacts should be reduced as the scale increases. In the LS or PP1,

4 the installed pumps and aerators were oversized. Accordingly, for the analysis of the LS

5 and PP1 reactors, it was not considered equipment which presented reduced energy

6 consumption. The reduction of LS to PP1 is significant of $56 \%$ while the reduction of

7 PP1 to FS represents only 9\%. This means that the environmental study would be

8 adequate from a reactor volume of $0.2 \mathrm{~m}$ if the process is optimised in terms of

$9 \quad$ installed power (pumps and aerators).

ELAN $^{\circledR}$ full-scale reactor, the emissions responsible for the climate change amount to

$4.62 \mathrm{~kg} \mathrm{CO}_{2} \mathrm{eq} / \mathrm{m}$. This suggests that the use of an $\mathrm{ELAN}^{\circledR}$ system instead of a

conventional nitrification/denitrification process in the sidestream could reduce emissions by approximately $57 \%$. Even for innovative alternatives such as the 
D 1 impngfrom the majoA

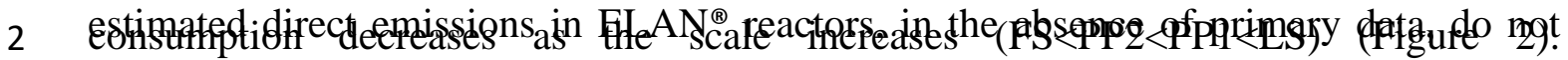

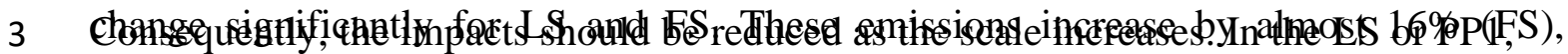

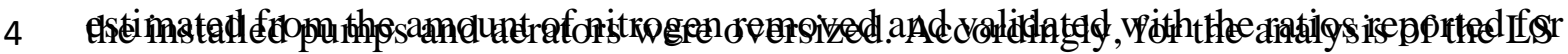

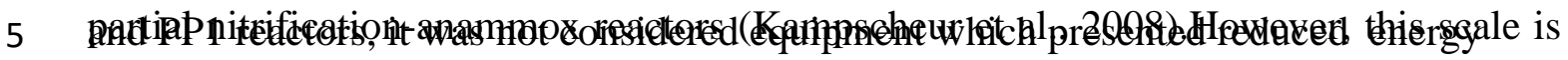
not relevant for comparison with the indirect emissions, which show an increase of approximately $55 \%$ from LS to FS reactors.

The conventional nitrification/denitrification processes have a higher electricity consumption than the $\mathrm{ELAN}^{\circledR}$ technology, which is mainly attributed to the energy use in the aeration process. The indirect emissions associated with the climate change category in conventional reactors are $10.37 \mathrm{~kg} \mathrm{CO}_{2} \mathrm{eq} / \mathrm{m}$ of treated effluent while in the

21 ELAN $^{\circledast}$ full-scale reactor, the emissions responsible for the climate change amount to

$224.62 \mathrm{~kg} \mathrm{CO}_{2} \mathrm{eq} / \mathrm{m}$. This suggests that the use of an ELAN ${ }^{\circledR}$ system instead of a

23 conventional nitrification/denitrification process in the sidestream could reduce

24 emissions by approximately $57 \%$. Even for innovative alternatives such as the

25 SHARON-Anammox technology (PN-AMX processes in separate units), the estimated 
1 direct emissions are comparatively higher (up to $13 \%$ for $\mathrm{NO}$ and $\mathrm{N}_{2} \mathrm{O}$ ) than in the

2 ELAN $^{\circledR}$ technology where PN-AMX takes place in a single unit (Kampschreur et al.,

3

4

5

6

7 2008; Van Dongen et al., 2001). The fact that low CC impact is produced indicates that the treatment costs will be presumably lower in the case of the $\mathrm{ELAN}^{\circledR}$ as well.

\subsection{Sensitivity analysis of the functional unit}

The functional unit is a relevant decision in the LCA methodology. The selection of two different functional units (one cubic meter of treated wastewater and $\mathrm{kg} \mathrm{TN}$ removed) for the eutrophication and climate change categories (Figure 5a and 5b) were investigated.

The category of climate change was considered because it is strongly dependent on indirect emissions of greenhouse gases derived from the consumption of electrical energy, especially during secondary treatment (Lorenzo-Toja et al., 2016a,b). The consideration of eutrophization finds its interest in the operation of nutrient removal systems for wastewater treatment. It has been reported that the implementation of a nitrificationdenitrificacion process implies a 54-58\% reduction in eutrophication potential in the mainstream of WWTPs (Larsen et al., 2007). However, ELAN ${ }^{\circledR}$ reactors upon being a sidestream (reactors in the sludge line) such as other reactors located in the same place, do not lead to the discharge of the treated effluent directly into water bodies, but it is treated its treated in a subsequent phosphorus recovery unit (struvite

precipitation) or it is returned to the headwaters of the WWTP (Morales et al., 2015b), causing no increase of the nitrogen load of the mainstream and improving as a consequence the quality of the effluent from the WWTP. Moreover, the only impact category that is not fundamentally dependent on electricity consumption is eutrophication potential. Figures $4 \mathrm{a}$ and $4 \mathrm{~b}$ show that the values of the two functional 
1 units are very similar. Therefore, the choice of another functional unit would not change

2 the results of this study and the appropriate size for an environmental study would

3

4

5 remain the same $\left(0.2 \mathrm{~m}^{3}\right.$ reactor $)$.

\subsection{Data representativeness and bottom-up techniques}

As indicated above, the composition of wastewater presents a significant degree of variability, which may condition the results of the LCA study. It is therefore important to validate the data, but sometimes this is difficult because a large number of measures are required and aggregation of the data into impact categories can mean the loss of a precise approach (Balkema et al., 2002). Figure 2 shows the impact assessment profile for the $\mathrm{CC}, \mathrm{EP}$ and $\mathrm{HT}$ categories per functional unit $\left(1 \mathrm{~m}^{3}\right.$ of wastewater) in relation to the standard error of the mean, i.e. the standard deviation of all possible data in relation to the number of iterations of the Monte Carlo analysis. For energy-dependent categories such as CC and HT, the most significative deviations occur at LS (Figure 2), this is due to the electricity consumption at this stage which is higher than in the other reactors. The uncertainty is reduced from approximately $78 \%$ in LS to $2 \%$ in FS. This is in agreement with the results of the study presented in the results section. Finally, in the EP category the variation between the different reactors is similar., which is attributed to its higher dependence on the effluent and influent conditions (COD, TN or TP). These parameters are actual measurements and in this study show less deviation and more consistency than the electrical process (background process).

There are profuse literature reports on large-scale environmental assessment of WWTP, but little information is available on the environmental and economic analysis of innovative technology under development. This study allows validating the bottomup techniques strategy in LCA studies, specifically for the analysis of innovative technologies in the field of wastewater treatment and management. Therefore, it is 
1 important to know at what point in the development of a technology it makes sense to

2 do LCA analyses in order to assess whether the technology is economically and

3 environmentally friendly. In addition, the hotspots of the final environmental impact can

4 be precisely known in the early stages of technology development, so that operational

5 strategies or design modifications can be introduced at later scales to minimize the final

6 impact.

7 In short, this paper indicates the turning point at the scale level from which the decision is made as to whether a technological innovation can be feasible or not and, therefore, continue the bottom-up strategy.

\subsection{Economic aspects}

To compare the magnitude of the cost presented by the $\mathrm{ELAN}^{\circledR}$ technology, the SCENA system (as an example of innovative technology applied at sidestream conditions) and the conventional activated slugde system (CAS) have been considered. For SCENA, the corresponding cost of electricity is $0.52 € / \mathrm{m}^{3}$ and it is double for CAS $\left(1.09 € / \mathrm{m}^{3}\right)$ (Renzi et al., 2015). However, the cost associated with ELAN ${ }^{\circledR}$ is lower $(0.27$ $€ / \mathrm{m}^{3}$ ) than those from SCENA and CAS (Renzi et al., 2015). SCENA system is more complex than $\mathrm{ELAN}^{\circledR}$ technology as it comprises a fermentation unit, a screw press filter and finally, a batch sequencing reactor (Frison et al., 2014). In this case, as the sequencing batch reactor is the unit where partial nitrification-denitrification takes place, this reactor was taken into account in the estimation of costs related energy consumption. An important question is to determine the level of technological development required for the estimation of accurate costs. In this case, the economic data shown in Figure 3 are similar for PP2 and FS. The PP1 value remains high compared to PP2 and FS, as it represents approximately $12 \%$ of the energy consumption 
1 cost. Therefore, an appropriate reactor volume to obtain an economic evaluation in

2 terms of operational costs is approximately $1 \mathrm{~m}^{3}$.

When it comes to evaluate the economic aspects for only one technology, it makes sense to use electricity-related operating costs for comparison. However, for different technologies, the implementation costs of one or the other technology are likely to be very different. One of the advantages that $\mathrm{ELAN}^{\circledR}$ process stands out from other technologies on the market is that cheaper robust probes are used and the reactor configuration is simpler than other options (Morales et al, 2015b).

\section{Conclusions}

After applying the LCA methodology to explore the minor reactor volume which provides reliable results to evaluate impacts from a developed technology a minimum volume of $0.2 \mathrm{~m}^{3}$ was selected. An environmental assessment can be made when the energy consumption (pumps and aerators)is optimised for the reactor size. This is because in eutrophication, which is the category that does not depend on energy consumption, the impact is practically the same for PP1, PP2 and FS. Therefore, it is possible to make an environmental assessment of the PP1 level. Regarding to the operational cost, the volume adequate to get an economic evaluation is approximately $1 \mathrm{~m}^{3}$.

\section{Acknowledgements}

This research was supported by the UE projects: Pioneer_STP (PCIN-2015-22 (MINECO)/ID199 (WaterJPI) and Run4Life (730285-1). The authors (A. Arias, I. Cámara Salim, A. Pedrouso, A. Mosquera-Corral, G. Feijoo and M.T. Moreira) belong to the Galician Competitive Research Group (GRC ED431C 2017/29) and to the CRETUS Strategic Partnership (AGRUP2015/02). The authors gratefully acknowledge the staff of Guillarei WWTP and 'Consorcio de Augas do Louro' for their assistance. 


\section{References}

2 Balkema, A.J., Preisig, H.A., Otterpohl, R., Lambert, F.J.D., 2002. Indicators for the sustainability assessment of wastewater treatment systems. Urban Water 4, 153161.

Dapena-Mora, A., Campos, J.L., Mosquera-Corral, A., Jetten, M.S.M., Méndez, R., 2004. Stability of the ANAMMOX process in a gas-lift reactor and a SBR. J. Biotechnol. $110,159-170$.

Dones R., Bauer C., Bolliger R., Burger B., Faist Emmenegger M., Frischknecht R., Heck T., Jungbluth N., Röder A., T.M., 2007. Life cycle inventories of energy systems: results of current systems in Switzerland and other UCTE countries. Ecoinvent Rep.5.

EC, 1991. Directive 91/271/1991 ECC of 21 May 1991 concerning urban waste water treatment. Official Journal of the European Communities L 135, 40-52.

EU, 2000. Directive 2000/60/EC of 23 October 2000 establishing a framework for community action in the field of water policy. Official Journal of the European Communities L. 327, 1-72.

Fantin, V., Giuliano, A., Manfredi, M., Ottaviano, G., Stefanova, M., Masoni, P., 2015. Environmental assessment of electricity generation from an Italian anaerobic digestion plant. Biomass and Bioenergy 83, 422-435.

Finnveden, G., 2000. On the limitations of life cycle assessment and environmental systems analysis tools in general. Int. J. Life Cycle Assess. 5, 229-238.

Foley, J., de Haas, D., Hartley, K., Lant, P., 2010a. Comprehensive life cycle inventories of alternative wastewater treatment systems. Water Res. $\quad 44,1654-$ 1666. 
1 Foley, J.M., Rozendal, R.A., Hertle, C.K., Lant, P.A., 2010b. Life Cycle Assessment of 2 High-Rate Anaerobic Treatment, Microbial Fuel Cells, and Microbial Electrolysis

3

4 Cells. Sci. Technol 44, 3629-3637.

Guo, M., Murphy, R.J., 2012. LCA data quality: Sensitivity and uncertainty analysis. Sci. Total Environ. 435-436, 230-243.

Huijbregts, M., 2002. Uncertainty and variability in environmental life-cycle assessment. Int. J. Life Cycle Assess. 7, 173.

Nicola Frison, Stefano Longo, Daniele Renzi and Francesco Fatone, 2015. "Short-Cut Enhanced Nutrients Abatement (SCENA) From Reject Water: Moving The System Into Practice”. Nutrient Removal and Recovery (NRR) Congress. International Water Association (IWA).

Gallego, A., Hospido, A., Moreira, M.T., Feijoo, G., 2008. Environmental performance of wastewater treatment plants for small populations. Resour. Conserv. Recycl. 52, 931-940.

Goedkoop, M., Heijungs, R., Huijbregts, M., Schryver, A. De, Struijs, J., Zelm, R. Van, 2009. ReCiPe 2008. Potentials 1-44.

Guinée, J., 2002. Handbook on Life Cycle Assessment Operational Guide to the ISO Standards. Environ. Impact Assess. Rev. 23, 129-130.

Heijungs, R., Huppes, G., Guinée, J.B., 2010. Life cycle assessment and sustainability analysis of products, materials and technologies. Toward a scientific framework for sustainability life cycle analysis. Polym. Degrad. Stab. 95, 422-428.

Hospido, A., Moreira, M.T., Fernández-Couto, M., Feijoo, G., 2004. Environmental performance of a municipal wastewater treatment plant. Int. J. Life Cycle Assess. 
1 Hospido, A., Sanchez, I., Rodriguez-Garcia, G., Iglesias, A., Buntner, D., Reif, R., Moreira, M.T., Feijoo, G., 2012. Are all membrane reactors equal from an environmental point of view? Desalination. 285, 263-270.

ISO, 2006. ISO 14040. Environmental management - life cycle assessment - principles and framework. International Standards Organization.

Jetten, M.S.M., Schmid, M., Schmidt, I., Wubben, M., van Dongen, U., Abma, W., Sliekers, O., Revsbech, N.P., Beaumont, H.J.E., Ottosen, L., Volcke, E., Laanbroek, H.J., Campos-Gomez, J.L., Cole, J., van Loosdrecht, M., Mulder, J.W., Fuerst, J., Richardson, D., van de Pas, K., Mendez-Pampin, R., Third, K., Cirpus, I., van Spanning, R., Bollmann, A., Nielsen, L.P., den Camp, H.O., Schultz, C., Gundersen, J., Vanrolleghem, P., Strous, M., Wagner, M., Kuenen, J.G., 2002. Improved nitrogen removal by application of new nitrogen-cycle bacteria. Rev. Environ. Sci. Biotechnol. 1, 51-63.

Kampschreur, M.J., van der Star, W.R.L., Wielders, H.A., Mulder, J.W., Jetten, M.S.M., van Loosdrecht, M.C.M., 2008. Dynamics of nitric oxide and nitrous oxide emission during full-scale reject water treatment. Water Res. 42, 812-826.

Kuai, L., Verstraete, W., 1998. Ammonium Removal by the Oxygen-Limited Autotrophic Nitrification-Denitrification System Ammonium Removal by the Oxygen-Limited Autotrophic Nitrification-Denitrification System. Appl. Environ. Microbiol. 64, $4500-4506$.

Larsen, H.F., Hauschild, M., Wenzel, H., Almemark, M., 2007. Homogeneous LCA methodology agreed by NEPTUNE and INNOWATECH. Denmark 1-34.

Lederer, J., Rechberger, H., 2010. Comparative goal-oriented assessment of conventional and alternative sewage sludge treatment options. Waste Manag. 30, 
2 Li, B., Brett, M.T., 2012. The impact of alum based advanced nutrient removal

3

4 processes on phosphorus bioavailability. Water Res. 46, 837-844

\section{Longo, S., Frison, N., Renzi, D., Fatone, F., Hospido, A., 2017. Is SCENA a good} approach for side-stream integrated treatment from an environmental and economic point of view? Water Res. 125, 478-489.

Lorenzo-Toja, Y., Alfonsín, C., Amores, M.J., Aldea, X., Marin, D., Moreira, M.T., Feijoo, G., 2016a. Beyond the conventional life cycle inventory in wastewater treatment plants. Sci. Total Environ. 553, 71-82.

Lorenzo-Toja, Y., Vázquez-Rowe, I., Amores, M.J., Termes-Rifé, M., Marín-Navarro, D., Moreira, M.T., Feijoo, G., 2016b. Benchmarking wastewater treatment plants under an eco-efficiency perspective. Sci. Total Environ. 566-567, 468-479.

Lundie, S., Peters, G.M., Beavis, P.C., 2004. Life Cycle Assessment for Sustainable

4 Metropolitan Water Systems Planning. Environ. Sci. Technol. 38, 3465-3473.

5 Machado, A.P., Urbano, L., Brito, A.G., Janknecht, P., Salas, J.J., Nogueira, R., 2007.

$\begin{array}{lll}16 & 58 & 23 \\ & 59 & \\ 17 & 60 & 24\end{array}$


L 1 ater łregłgent options for small and decentralized communities. Water Sci. Technol. i $56,15-22$

2 Li, B., Brett, M.T., 2012. The impact of alum based advanced nutrient removal

3 Machadges controllers design based on the relative gain array for a nutrient removal WWTP. 4 Longo, S., Frison, N., Renzi, D., Fatone, F., Hospido, A., 2017. Is SCENA a good Water Res. 43, 5129-5141.

Morales, N., Val Del Río, A., Vázquez-Padín, J.R., Gutiérrez, R., Fernández-González, $\mathrm{c}$ R., Icaran, P., Rogalla, F., Campos, J.L., Méndez, R., Mosquera-Corral, A., 2015a. 1 Influence of dissolved oxygen concentration on the start-up of the anammox-based process: ELAN ${ }^{\circledR}$ Water Sci. Technol. 72, 520-527.

a 
1 Morales, N., Val del Río, Á., Vázquez-Padín, J.R., Méndez, R., Mosquera-Corral, A.,

2 Campos, J.L., 2015b. Integration of the Anammox process to the rejection water and main stream lines of WWTPs. Chemosphere 140, 99-105.

Mosquera-Corral, A., González, F., Campos, J.L., Méndez, R., 2005. Partial nitrification in a SHARON reactor in the presence of salts and organic carbon compounds. Process Biochem. 40, 3109-3118.

Pasqualino, J.C., Meneses, M., Castells, F., 2011. Life Cycle Assessment of Urban Wastewater Reclamation and Reuse Alternatives. J. Ind. Ecol. 15, 49-63.

REE. Red Eléctrica de España, 2017. Avance del Informe del sistema elétrico español 2016. Red Eléctrica de España, Madrid.

Reap, J., Roman, F., Duncan, S., Bras, B., 2008. A survey of unresolved problems in life cycle assessment. Part 2: Impact assessment and interpretation. Int. J. Life Cycle Assess. 13, 374-388.

Renzi, D., Longo, S., Frison, N., Malamis, S., Katsou, E.,Fatone, F., 2015 Short-cut enhanced nutrient removal from anaerobic supernatants: Pilot scale results and full scale development of the S.C.E.N.A process. Sewage Treatment Plants. Economic Evaluation of Innovative Technologies for Energy Efficiency. IWA publishinig London, pp.1-94.

Rodriguez-Garcia, G., Molinos-Senante, M., Hospido, A., Hernández-Sancho, F., Moreira, M.T., Feijoo, G., 2011. Environmental and economic profile of six typologies of wastewater treatment plants. Water Res. 45, 5997-6010.

Tillman, A.-M., 2000. Significance of decision making for LCA methodology. Environ. Impact Assess. Rev. 20, 113-123.

Van Dongen, U., Jetten, M.S.M., Van Loosdrecht, M.C.M., 2001. The SHARON®- 
Anammox ${ }^{\circledR}$ process for treatment of ammonium rich wastewater. Water Sci.

2 Technol. 44, 153-160.

Vázquez-Padín, J.R., Pozo, M.J., Jarpa, M., Figueroa, M., Franco, A., Mosquera-Corral, A., Campos, J.L., Méndez, R., 2009. Treatment of anaerobic sludge digester effluents by the CANON process in an air pulsing SBR. J. Hazard. Mater. 166, $336-341$.

Vázquez-Padín, J., Mosquera-Corral, A., Campos, J.L., Méndez, R., Revsbech, N.P., 2010. Microbial community distribution and activity dynamics of granular biomass in a CANON reactor. Water Res. 44, 4359-4370.

Vázquez-Padín, J.R., Morales, N., Gutiérrez, R., Fernández, R., Rogalla, F., Barrio, J.P., Campos, J.L., Mosquera-Corral, A., Méndez, R., 2014a. Implications of full-scale implementation of an anammox-based process as post-treatment of a municipal anaerobic sludge digester operated with co-digestion. Water Sci. Technol. 69, 11511158.

Vazquez Padin, J.R., Morales, N., Icaran, P., Gutiérrez, R., Fernández González, R., Rogalla, F., Val del Río, Á., Campos, J.L., 2014b. Implantación del sistema ELAN para la eliminación sostenible de nitrógeno en la línea de retorno de la EDAR de Guillarei (Tui, Pontevedra). Retema 60-66.

Vidal, N., Poch, M., Marti, E., Rodriguez-Roda, I., 2002. Evaluation of the environmental implications to include structural changes in a wastewater treatment plant. J. Chem. Technol. Biotechnol. 77, 1206-1211.

Wang, X., Liu, J., Ren, N.Q., Duan, Z., 2012. Environmental profile of typical anaerobic/anoxic/oxic wastewater treatment systems meeting increasingly stringent treatment standards from a life cycle perspective. Bioresour. Technol. 126, 31-40. 
1 Weidema, B.P., 2003. Market information in life cycle assessment. Danish Minist.

2 Environ. 863, 147.

3 Yoshida, H., Clavreul, J., Scheutz, C., Christensen, T.H., 2014. Influence of data

$4 \quad$ collection schemes on the Life Cycle Assessment of a municipal wastewater $5 \quad$ treatment plant. Water Res. 56, 292-303.

6 Zang, Y., Li, Y., Wang, C., Zhang, W., Xiong, W., 2015. Towards more accurate life 7 cycle assessment of biological wastewater treatment plants: A review. J. Clean. 8 Prod. 107, 676-692. 


\section{Figure Captions}

Figure 1. Scheme of operational cycle in the reactors operated at different scale for the development of the ELAN $^{\circledR}$ process.

Figure 2. Comparison of environmental impacts obtained from the different reactor sizes:(including standard deviations): (a) Climate Change (CC) (b) Eutrophication Potential (EP) (c) Human Toxicity (HT) impacts.

Figure 3. Climate Change impact and cost per cubic meter of treated wastewater.

Acronyms: LS: $1.5 \mathrm{~L}, \mathrm{PP} 1: 0.2 \mathrm{~m}^{3}$, PP2: $1.2 \mathrm{~m}^{3}$ and FS: $97 \mathrm{~m}^{3}$

Figure 4. Coefficient of variation for each reactor.

Figure 5. a) Comparison between two different functional units $\left(1 \mathrm{~m}^{3}\right.$ of treated wastewater and $\mathrm{kg}$ TN removal) for the eutrophication category. b) Comparison between two different functional units $\left(1 \mathrm{~m}^{3}\right.$ of treated wastewater and $\mathrm{kg} \mathrm{TN}$ removal $)$ for the climate change category. Acronyms: LS: $1.5 \mathrm{~L}, \mathrm{PP} 1: 0.2 \mathrm{~m}^{3}, \mathrm{PP} 2: 1.2 \mathrm{~m}^{3}$ and FS: $97 \mathrm{~m}^{3}$ 
ELAN $^{\circledR}$ TECHNOLOGY

SEQUENCING BATCH REACTOR

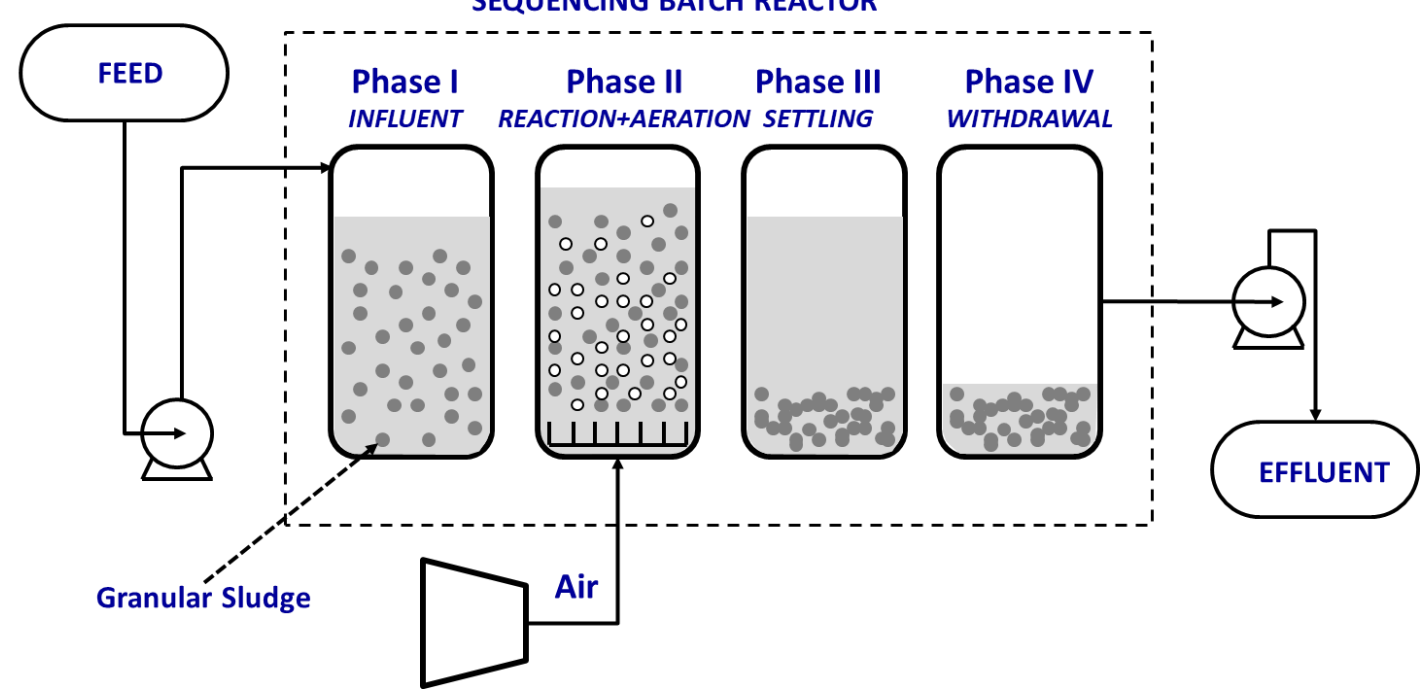

Figure 1 

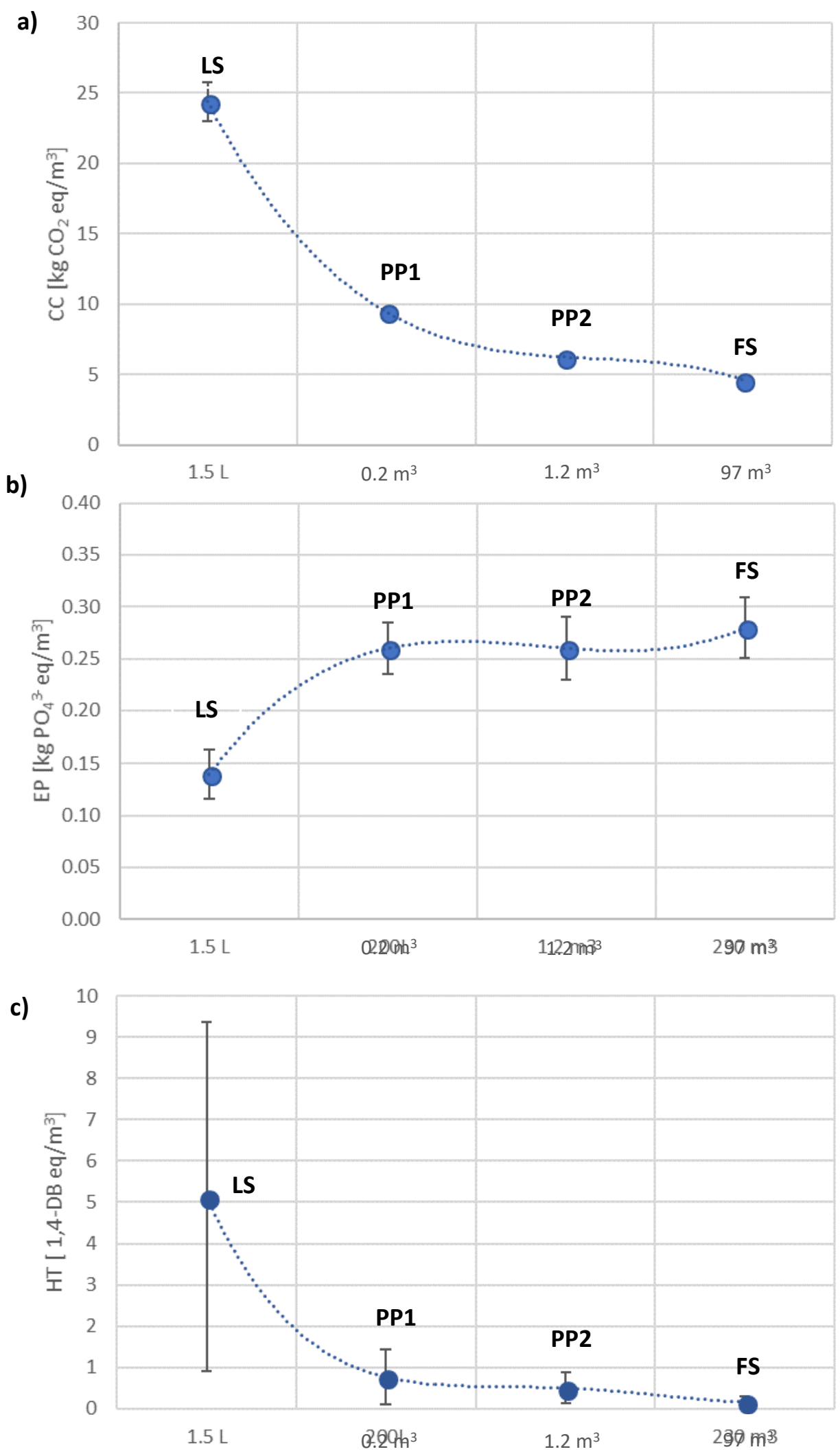

Figure 2 


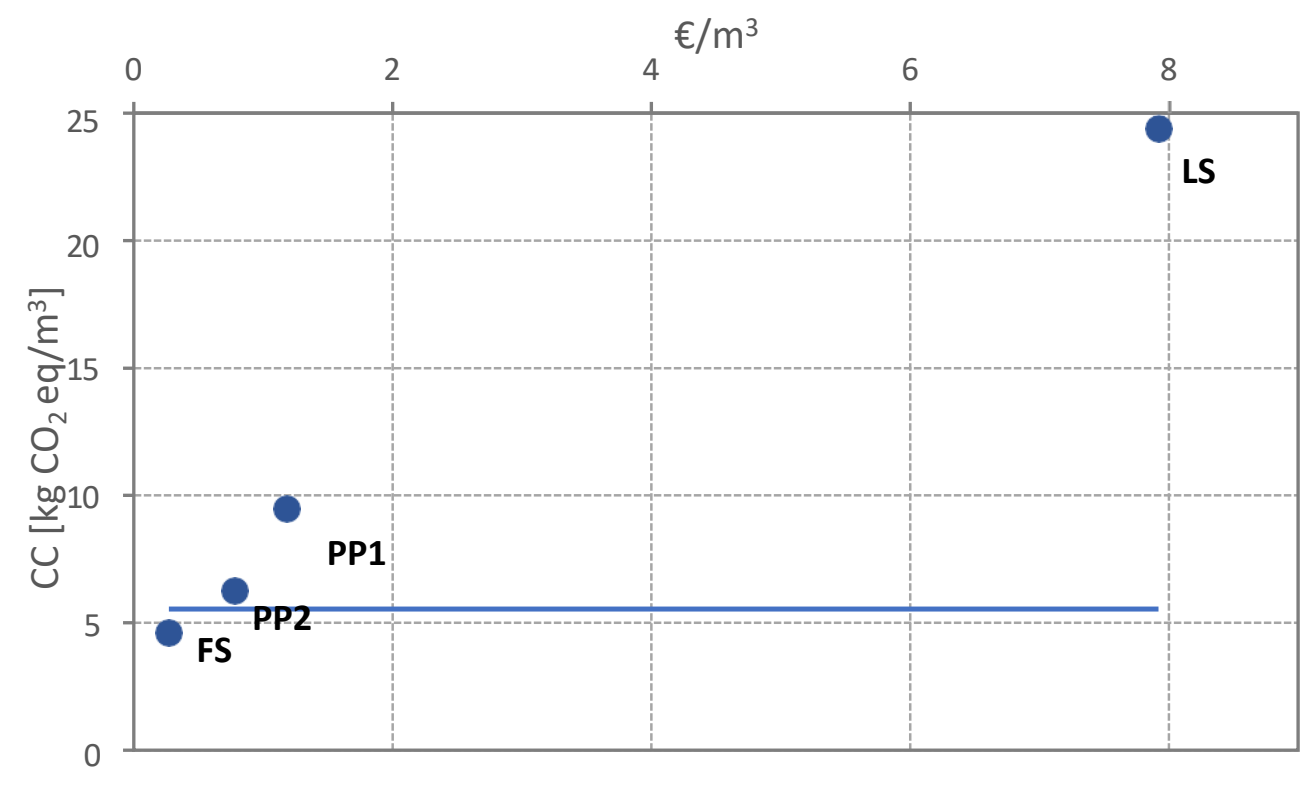

Figure 3 


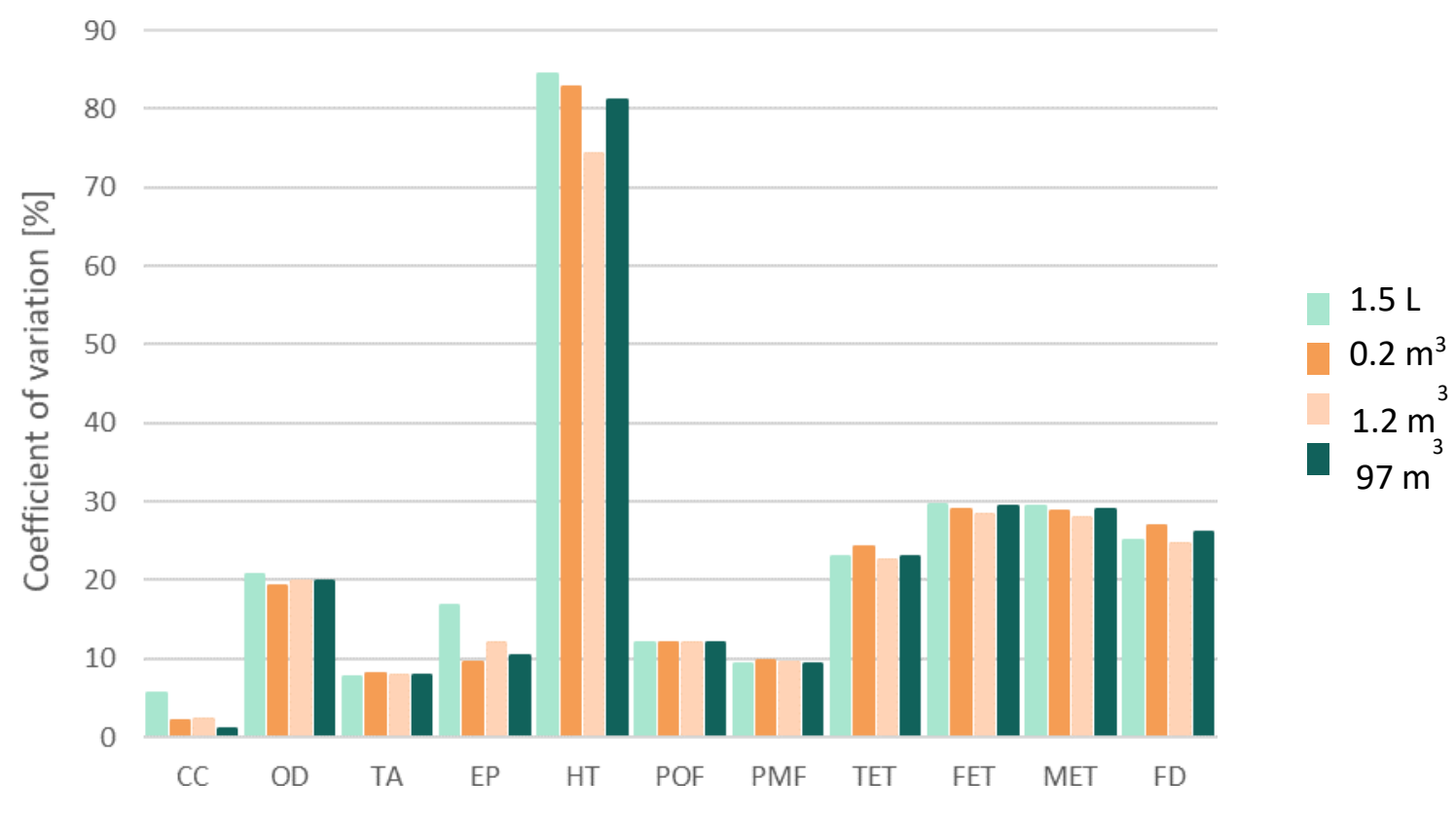

Figure 4 

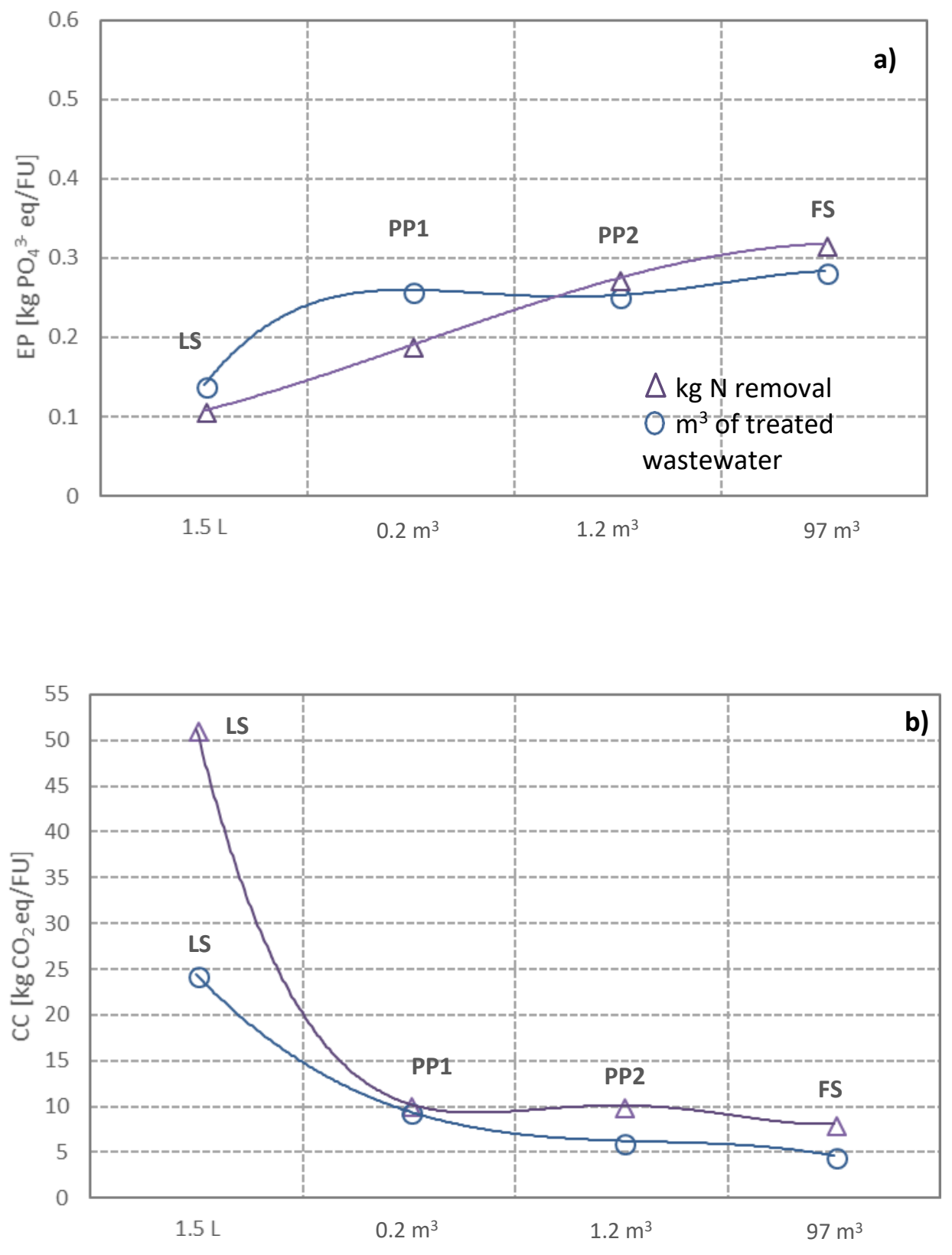

Figure 5 
Table 1. Description of the technical characteristics and operational conditions corresponding to the different evaluated reactors resulting in the ELAN ${ }^{\circledR}$ technology development (Morales et al., 2015a; Vázquez-Padín et al., 2009)

\begin{tabular}{|c|c|c|c|c|}
\hline & LS* & PP1 & PP2 & FS \\
\hline Material & Glass & Stainless Steel & Glass-Fiber & Reinforced concrete \\
\hline $\begin{array}{l}\text { Volume } \\
\text { Installed Power }\end{array}$ & $1.5 \mathrm{~L}$ & $0.2 \mathrm{~m}^{3}$ & $1.2 \mathrm{~m}^{3}$ & $115 \mathrm{~m}^{3}$ (97 useful volume) \\
\hline$\left(\mathrm{kW} / \mathrm{m}^{3}\right)$ & 140 & 16.5 & 0.90 & 0.16 \\
\hline $\mathrm{T}\left({ }^{\circ} \mathrm{C}\right)$ & $18-24$ & $24-30$ & $24-30$ & $24-30$ \\
\hline pH & 7.7 & 7.4 & 7.7 & 7.5 \\
\hline VER (\%) & 25 & 25 & 21 & 44 \\
\hline HRT (d) & 0.5 & 1 & 1.2 & 0.75 \\
\hline $\mathrm{DO}(\mathrm{mg} \mathrm{O} / \mathrm{L})$ & 0.5 & 1.5 & 0.5 & $0.2-0.5$ \\
\hline$N L R\left(k g ~ N / m^{3} \cdot d\right)$ & 0.25 & 0.77 & 0.45 & 0.46 \\
\hline
\end{tabular}

*LS: Laboratory Scale; PP: Pilot Plant; FS: Full Scale 
Table 2. Life Cycle Inventory of LS (1.5 L) per $1 \mathrm{~m}^{3}$ of treated wastewater. Adapted from Vazquez-Padín et al., (2009)

\begin{tabular}{|c|c|c|c|}
\hline \multicolumn{2}{|c|}{ INPUTS } & \multicolumn{2}{|l|}{ OUTPUTS } \\
\hline \multicolumn{2}{|c|}{ From the technosphere } & \multicolumn{2}{|c|}{ To the environment } \\
\hline Materials and fuel & & Emissions to water & \\
\hline Water Influent & & $\operatorname{COD}(\mathrm{g})$ & $95.1 \pm 54.1$ \\
\hline $\operatorname{COD}(\mathrm{g})$ & $278.5 \pm 155.6$ & $\mathrm{TN}(\mathrm{g})$ & $51.8 \pm 32.4$ \\
\hline $\mathrm{TN}(\mathrm{g})$ & $233.4 \pm 27.9$ & $\mathrm{NO}_{2}^{-}-\mathrm{N}(\mathrm{g})$ & $0.6 \pm 0.3$ \\
\hline $\mathrm{NH}_{4}^{+}-\mathrm{N}(\mathrm{g})$ & $233.4 \pm 27.9$ & $\mathrm{NO}_{3}^{-}-\mathrm{N}(\mathrm{g})$ & $28.5 \pm 4.6$ \\
\hline $\mathrm{TP}(\mathrm{g})$ & $47 \pm 16.1$ & $\mathrm{NH}_{4}^{+}-\mathrm{N}(\mathrm{g})$ & $25.7 \pm 15.2$ \\
\hline Electricity consump & & $\mathrm{TP}(\mathrm{g})$ & $33 \pm 12.3$ \\
\hline Aeration (kWh) & 60 & Emissions to air & \\
\hline Feeding (kWh) & 4.8 & NO (mg) & 0.001 \\
\hline \multirow[t]{4}{*}{ Emptying (kWh) } & 1 & $\mathrm{~N}_{2} \mathrm{O}(\mathrm{mg})$ & 0.01 \\
\hline & & \multicolumn{2}{|c|}{ To the technosphere } \\
\hline & & Products and co-products & \\
\hline & & Net Sludge production (g TSS) & 0 \\
\hline
\end{tabular}


Table 3. Life Cycle Inventory of PP1 $\left(0.2 \mathrm{~m}^{3}\right)$ per $1 \mathrm{~m}^{3}$ of treated wastewater (data supplied by Aqualia)

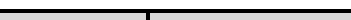

\begin{tabular}{|c|c|c|c|}
\hline \multicolumn{2}{|c|}{ INPUTS } & \multicolumn{2}{|l|}{ OUTPUTS } \\
\hline \multicolumn{2}{|c|}{ From the technosphere } & \multicolumn{2}{|l|}{ To the environment } \\
\hline \multirow{2}{*}{\multicolumn{2}{|c|}{$\begin{array}{l}\text { Materials and fuel } \\
\text { Influent }\end{array}$}} & \multicolumn{2}{|l|}{ Emissions to water } \\
\hline & & TSS (g) & $0.26 \pm 0.19$ \\
\hline TSS (g) & $0.52 \pm 0.44$ & VSS (g) & $0.23 \pm 0.16$ \\
\hline VSS (g) & $0.40 \pm 0.26$ & COD $(g)$ & $214 \pm 29.2$ \\
\hline $\operatorname{COD}(\mathrm{g})$ & $405 \pm 95.3$ & $\mathrm{TN}(\mathrm{g})$ & $202.9 \pm 69.9$ \\
\hline $\mathrm{TN}(\mathrm{g})$ & $1122 \pm 272$ & $\mathrm{NO}_{2}^{-}-\mathrm{N}(\mathrm{g})$ & $1.86 \pm 1.0$ \\
\hline $\mathrm{NO}_{2}^{-}-\mathrm{N}(\mathrm{g})$ & 0 & $\mathrm{NO}_{3}^{-}-\mathrm{N}(\mathrm{g})$ & $53 \pm 25$ \\
\hline $\mathrm{NO}_{3}^{-}-\mathrm{N}(\mathrm{g})$ & 0 & $\mathrm{NH}_{4}^{+}-\mathrm{N}(\mathrm{g})$ & $148 \pm 43.9$ \\
\hline $\mathrm{NH}_{4}^{+}-\mathrm{N}(\mathrm{g})$ & $1122 \pm 272$ & $\mathrm{TP}(\mathrm{g})$ & $36.5 \pm 12.3$ \\
\hline $\mathrm{TP}(\mathrm{g})$ & $48 \pm 16.1$ & \multicolumn{2}{|l|}{ Emissions to air } \\
\hline \multicolumn{2}{|c|}{ Electricity consumption } & $\mathrm{CO}_{2}(\mathrm{mg})$ & 3.79 \\
\hline Aeration (kWh) & 7.37 & $\mathrm{NO}(\mathrm{mg})$ & 0.002 \\
\hline Feeding (kWh) & 1.25 & $\mathrm{~N}_{2} \mathrm{O}(\mathrm{mg})$ & 0.02 \\
\hline \multirow[t]{3}{*}{ Emptying (kWh) } & \multirow[t]{3}{*}{1.25} & \multicolumn{2}{|c|}{ To the technosphere } \\
\hline & & \multicolumn{2}{|l|}{ Products and co-products } \\
\hline & & Net Sludge production (g TSS) & 0 \\
\hline
\end{tabular}


Table 4. Life Cycle Inventory of PP2 $\left(1.2 \mathrm{~m}^{3}\right)$ per $1 \mathrm{~m}^{3}$ of treated wastewater (data supplied by Aqualia company)

\begin{tabular}{|c|c|c|c|}
\hline \multicolumn{2}{|c|}{ INPUTS } & \multicolumn{2}{|l|}{ OUTPUTS } \\
\hline \multicolumn{2}{|c|}{ From the technosphere } & \multicolumn{2}{|l|}{ To the environment } \\
\hline \multirow{2}{*}{\multicolumn{2}{|c|}{$\begin{array}{l}\text { Materials and fuel } \\
\text { Influent }\end{array}$}} & \multicolumn{2}{|l|}{ Emissions to water } \\
\hline & & TSS (g) & $0.24 \pm 0.3$ \\
\hline TSS (g) & $0.42 \pm 0.5$ & VSS (g) & $0.18 \pm 0.2$ \\
\hline VSS (g) & $0.20 \pm 0.1$ & $\operatorname{COD}(\mathrm{g})$ & $152 \pm 104$ \\
\hline $\operatorname{COD}(\mathrm{g})$ & $229 \pm 141$ & $\mathrm{TN}(\mathrm{g})$ & $216.4 \pm 84$ \\
\hline $\mathrm{TN}(\mathrm{g})$ & $808 \pm 162.8$ & $\mathrm{NO}_{2}^{-}-\mathrm{N}(\mathrm{g})$ & $2.40 \pm 3.6$ \\
\hline $\mathrm{NO}_{2}^{-}-\mathrm{N}(\mathrm{g})$ & 0.00 & $\mathrm{NO}_{3}^{-}-\mathrm{N}(\mathrm{g})$ & $75 \pm 38.5$ \\
\hline $\mathrm{NO}_{3}^{-}-\mathrm{N}(\mathrm{g})$ & 0.00 & $\mathrm{NH}_{4}^{+}-\mathrm{N}(\mathrm{g})$ & $139 \pm 83.7$ \\
\hline $\mathrm{NH}_{4}^{+}-\mathrm{N}(\mathrm{g})$ & $808 \pm 162.8$ & $\mathrm{TP}(\mathrm{g})$ & $33.6 \pm 4.5$ \\
\hline $\mathrm{TP}(\mathrm{g})$ & $47 \pm 3.71$ & \multicolumn{2}{|l|}{ Emissions to air } \\
\hline \multicolumn{2}{|l|}{ Electricity consumption } & $\mathrm{CO}_{2}(\mathrm{mg})$ & 5.89 \\
\hline Aeration (kWh) & 5.98 & NO (mg) & 0.001 \\
\hline Feeding (kWh) & 0.26 & $\mathrm{~N}_{2} \mathrm{O}(\mathrm{mg})$ & 0.01 \\
\hline \multirow[t]{3}{*}{ Emptying (kWh) } & \multirow[t]{3}{*}{0.26} & \multicolumn{2}{|l|}{ To the technosphere } \\
\hline & & Products and co-products & \\
\hline & & Net Sludge production (g TSS) & 0 \\
\hline
\end{tabular}


Table 5. Life Cycle Inventory of FS $\left(97 \mathrm{~m}^{3}\right)$ per $1 \mathrm{~m}^{3}$ of treated wastewater (data supplied by Aqualia company)

\begin{tabular}{|c|c|c|c|}
\hline \multicolumn{2}{|c|}{ INPUTS } & \multicolumn{2}{|l|}{ OUTPUTS } \\
\hline \multicolumn{2}{|c|}{ From the technosphere } & \multicolumn{2}{|c|}{ To the environment } \\
\hline \multicolumn{2}{|l|}{ Materials and fuel } & \multicolumn{2}{|l|}{ Emissions to water } \\
\hline \multicolumn{2}{|l|}{ Water Influent } & TSS (g) & $0.3 \pm 0.2$ \\
\hline TSS (g) & $0.4 \pm 0.4$ & VSS (g) & $0.2 \pm 0.1$ \\
\hline VSS (g) & $0.2 \pm 0.4$ & $\operatorname{COD}(\mathrm{g})$ & $171.3 \pm 31$ \\
\hline $\operatorname{COD}(\mathrm{g})$ & $284.1 \pm 55.2$ & $\mathrm{TN}(\mathrm{g})$ & $228.8 \pm 55.8$ \\
\hline $\mathrm{TN}(\mathrm{g})$ & $797.7 \pm 102.8$ & $\mathrm{NO}_{2}^{-}-\mathrm{N}(\mathrm{g})$ & $5.9 \pm 6.1$ \\
\hline $\mathrm{NO}_{2}^{-}-\mathrm{N}(\mathrm{g})$ & 0.00 & $\mathrm{NO}_{3}^{-}-\mathrm{N}(\mathrm{g})$ & $93.1 \pm 18.3$ \\
\hline $\mathrm{NO}_{3}^{-}-\mathrm{N}(\mathrm{g})$ & 0.00 & $\mathrm{NH}_{4}^{+}-\mathrm{N}(\mathrm{g})$ & $109.7 \pm 23.2$ \\
\hline $\mathrm{NH}_{4}^{+}-\mathrm{N}(\mathrm{g})$ & $569.1 \pm 20.4$ & $\mathrm{TP}(\mathrm{g})$ & $44.8 \pm 17.6$ \\
\hline $\mathrm{TP}(\mathrm{g})$ & $61.2 \pm 34.9$ & \multicolumn{2}{|l|}{ Emissions to air } \\
\hline \multicolumn{2}{|c|}{ Electricity consumption } & $\mathrm{CO}_{2}(\mathrm{mg})$ & 6.1 \\
\hline Aeration (kWh) & 2.2 & $\mathrm{NO}(\mathrm{mg})$ & 0.001 \\
\hline Feeding (kWh) & 0.1 & $\mathrm{~N}_{2} \mathrm{O}(\mathrm{mg})$ & 0.01 \\
\hline \multirow[t]{3}{*}{ Emptying (kWh) } & \multirow[t]{3}{*}{0.01} & \multicolumn{2}{|c|}{ To the technosphere } \\
\hline & & \multicolumn{2}{|l|}{ Products and co-products } \\
\hline & & Net Sludge production (g TSS) & 0 \\
\hline
\end{tabular}


Table 6. Environmental results of the different reactors, resulting in the ELAN ${ }^{\circledR}$ process, for the impact categories under assesment. FU: $1 \mathrm{~m}^{3}$ of treated wastewater. Acronyms: LS: $1.5 \mathrm{~L}, \mathrm{PP} 1: 0.2 \mathrm{~m}^{3}$, PP2: $1.2 \mathrm{~m}^{3}$ and FS: $97 \mathrm{~m}^{3}$

\begin{tabular}{|c|c|c|c|c|}
\hline Impact Categories & LS & PP1 & PP2 & FS \\
\hline $\begin{array}{l}\text { Climate change (CC) } \\
\quad\left(\mathrm{kg} \mathrm{CO}{ }_{2} \mathrm{eq}\right)\end{array}$ & 24.39 & 9.46 & 6.24 & 4.62 \\
\hline $\begin{array}{l}\text { Ozone depletion (OD) } \\
\quad(\text { kg CFC-11 eq) }\end{array}$ & $3.02 \cdot 10^{-6}$ & $4.51 \cdot 10^{-7}$ & $2.97 \cdot 10^{-7}$ & $1.02 \cdot 10^{-7}$ \\
\hline $\begin{array}{c}\text { Terrestrial acidification } \\
\text { (TA) } \\
\left(\mathrm{kg} \mathrm{SO}_{2} \text { eq }\right)\end{array}$ & 0.12 & 0.02 & 0.01 & $4.17 \cdot 10^{-3}$ \\
\hline $\begin{array}{l}\text { Eutrophication (EP) } \\
\qquad\left(\mathrm{kg} \mathrm{PO}_{4}{ }^{3-} \text { eq) }\right.\end{array}$ & 0.14 & 0.26 & 0.25 & 0.28 \\
\hline $\begin{array}{l}\text { Human toxicity (HT) } \\
\qquad(\mathrm{kg} \mathrm{1,4-DCB} \mathrm{eq)}\end{array}$ & 5.13 & 0.77 & 0.50 & 0.17 \\
\hline $\begin{array}{c}\text { Photochemical } \\
\text { Oxidation Formation } \\
\text { (POF) } \\
\text { (kg NMVOC) }\end{array}$ & 0.06 & 0.01 & 0.01 & $2.11 \cdot 10^{-3}$ \\
\hline $\begin{array}{l}\text { Particulate Matter } \\
\text { Formation (PMF) } \\
\quad\left(\mathrm{kg} \mathrm{PM}_{10} \mathrm{eq}\right)\end{array}$ & 0.04 & 0.01 & $4.30 \cdot 10^{-3}$ & $1.48 \cdot 10^{-3}$ \\
\hline $\begin{array}{c}\text { Terrestrial Ecotoxicity } \\
\text { (TET) } \\
\text { kg 1,4-DCB eq) }\end{array}$ & $5.33 \cdot 10^{-4}$ & $7.97 \cdot 10^{-5}$ & $5.25 \cdot 10^{-5}$ & $1.81 \cdot 10^{-5}$ \\
\hline $\begin{array}{c}\text { Freshwater Ecotoxicity } \\
\text { (FET) } \\
(\mathrm{kg} \mathrm{1,4-DCB} \mathrm{eq)}\end{array}$ & 0.38 & 0.06 & 0.04 & 0.01 \\
\hline $\begin{array}{c}\text { Marine Ecotoxicity } \\
\text { (MET) } \\
\text { (kg 1,4-DCB eq) }\end{array}$ & 0.34 & 0.06 & 0.04 & 0.01 \\
\hline $\begin{array}{l}\text { Water Depletion (WD) } \\
\qquad\left(\mathrm{m}^{3}\right)\end{array}$ & 0.19 & 0.03 & 0.02 & 0.01 \\
\hline $\begin{array}{l}\text { Fossil Depletion (FD) } \\
\quad(\mathrm{kg} \text { oil eq) }\end{array}$ & 5.39 & 0.80 & 0.53 & 0.18 \\
\hline
\end{tabular}




\title{
Bottom-up approach in the assessment of environmental impacts and costs of an innovative anammox-based process for nitrogen removal
}

\author{
Andrea Arias ${ }^{\mathrm{a}, *}$, Iana Salima, Alba Pedrouso ${ }^{\mathrm{a}}$, Nicolás Morales ${ }^{\mathrm{b}}$, Anuska Mosquera- \\ Corral $^{\mathrm{a}}$, José Ramón Vázquez-Padín ${ }^{\mathrm{b}}$, Frank Rogalla ${ }^{\mathrm{b}}$, Gumersindo Feijoo ${ }^{\mathrm{a}}$, María Tere- \\ sa Moreira ${ }^{\mathrm{a}}$ \\ ${ }^{a}$ Department of Chemical Engineering, School of Enginering, Universidade de Santiago de Compostela, \\ E-15782, Santiago de Compostela, Galicia, Spain \\ ${ }^{\mathrm{b}}$ Aqualia, Guillarei WWTP, Camino de la Veiga s/n, E-36720, Tui, Spain \\ * Corresponding author. E-mail: andrea16_verin@ @otmail.com
}




\subsection{Uncertainty analysis results}

Table S1. Uncertainty values for the LS reactor ( $\mathrm{V}=1.5 \mathrm{~L})$. Acronyms: CV: coefficient of variation; SEM: standard error of the mean.

\begin{tabular}{|c|c|c|c|c|c|c|c|}
\hline $\begin{array}{c}\text { Impact } \\
\text { Categories }\end{array}$ & Mean & Median & $\begin{array}{l}\text { Standard } \\
\text { deviation }\end{array}$ & $\mathrm{CV}$ & $2.5 \%$ & $97.5 \%$ & SEM \\
\hline $\begin{array}{c}\text { Climate change } \\
(\mathrm{CC}) \\
(\mathrm{kg} \mathrm{CO} 2 \mathrm{eq})\end{array}$ & 24.39 & 24.16 & 1.38 & 5.64 & 22.35 & 27.95 & 0.04 \\
\hline $\begin{array}{l}\text { OzondQBpletion } \\
\text { (kg CFC-11 eq) }\end{array}$ & $3.0 \cdot 10^{-6}$ & $3.0 \cdot 10^{-6}$ & $6.2 \cdot 10^{-7}$ & 20.63 & $2 \cdot 10^{-6}$ & $4.5 \cdot 10^{-6}$ & $1.97 \cdot 10^{-8}$ \\
\hline $\begin{array}{c}\text { Terrestrial } \\
\text { acidification } \\
(\mathrm{TA}) \\
\left(\mathrm{kg} \mathrm{SO}_{2} \text { eq) }\right.\end{array}$ & 0.12 & 0.12 & 0.01 & 7.60 & 0.11 & 0.15 & $2.96 \cdot 10^{-4}$ \\
\hline $\begin{array}{c}\text { Eutrophication } \\
\text { (EP) } \\
\left(\mathrm{kg} \mathrm{PO}_{4}{ }^{3-} \text { eq }\right)\end{array}$ & 0.14 & 0.14 & 0.02 & 16.69 & 0.10 & 0.19 & $7.57 \cdot 10^{-4}$ \\
\hline $\begin{array}{c}\text { Human toxicity } \\
\text { (HT) } \\
\text { (kg 1,4-DCB eq) }\end{array}$ & 5.01 & 4.01 & 4.23 & 84.47 & 1.87 & 14.24 & 0.13 \\
\hline $\begin{array}{c}\text { Photochemical } \\
\text { Oxidation } \\
\text { Formation } \\
\text { (POF) } \\
\text { (kg NMVOC) }\end{array}$ & 0.06 & 0.06 & 0.01 & 12.03 & 0.05 & 0.08 & $2.37 \cdot 10^{-4}$ \\
\hline $\begin{array}{l}\text { Particulate } \\
\text { Matter } \\
\text { Formation } \\
(\text { PMF }) \\
\left(\text { kg PM } \text { PM }_{10} \text { eq }\right)\end{array}$ & 0.04 & 0.04 & 0.00 & 9.25 & 0.04 & 0.05 & $1.28 \cdot 10^{-4}$ \\
\hline $\begin{array}{l}\text { Terrestrial } \\
\text { Ecotoxicity } \\
\text { (TET) }\end{array}$ & $5.3 \cdot 10^{-4}$ & $5.1 \cdot 10^{-4}$ & $1.2 \cdot 10^{-4}$ & 22.97 & $3.6 \cdot 10^{-4}$ & $8.3 \cdot 10^{-4}$ & $3.9 \cdot 10^{-6}$ \\
\hline $\begin{array}{l}\text { Freshwater } \\
\text { Ecotoxicity } \\
(\text { FET) }\end{array}$ & 0.38 & 0.36 & 0.11 & 29.58 & 0.22 & 0.67 & $3.58 \cdot 10^{-3}$ \\
\hline $\begin{array}{c}\text { Marine } \\
\text { Ecotoxicity } \\
(\text { MET) }\end{array}$ & 0.34 & 0.32 & 0.10 & 29.43 & 0.20 & 0.59 & $3.17 \cdot 10^{-3}$ \\
\hline
\end{tabular}


(kg 1,4-DCB eq)

Fossil Depletion

(FD)

5.40

1.35

25.06

3.44

8.57

0.04

57

(kg oil eq) 
Table S2. Uncertainty values for the PP1 reactor (V=200 L). Acronyms: CV: coefficient of variation; SEM: standard error of the mean.

\begin{tabular}{|c|c|c|c|c|c|c|c|}
\hline $\begin{array}{c}\text { Impact } \\
\text { Categories }\end{array}$ & Mean & Median & $\begin{array}{l}\text { Standard } \\
\text { deviation }\end{array}$ & $\mathrm{CV}$ & $2.5 \%$ & $97.5 \%$ & SEM \\
\hline $\begin{array}{c}\text { Climate change } \\
(\mathrm{CC}) \\
\left(\mathrm{kg} \mathrm{CO} \mathrm{CO}_{2} \mathrm{eq}\right)\end{array}$ & 9.45 & 9.42 & 0.19 & 2.04 & 9.15 & 9.90 & 0.01 \\
\hline $\begin{array}{c}\text { Ozone depletion } \\
\text { (OD) } \\
\text { (kg CFC-11 eq) }\end{array}$ & $4.5 \cdot 10^{-7}$ & $4.4 \cdot 10^{-8}$ & $8.6 \cdot 10^{-8}$ & 19.16 & $3.1 \cdot 10^{-7}$ & $6.6 \cdot 10^{-7}$ & $2.7 \cdot 10^{-9}$ \\
\hline $\begin{array}{c}\text { Terrestrial } \\
\text { acidification } \\
(\mathrm{TA}) \\
\left(\mathrm{kg} \mathrm{SO} \mathbf{S}_{2} \mathbf{e q}\right)\end{array}$ & 0.02 & 0.02 & 0.00 & 8.13 & 0.02 & 0.02 & $4.7 \cdot 10^{-5}$ \\
\hline $\begin{array}{c}\text { Eutrophication } \\
\text { (EP) } \\
\left(\mathrm{kg} \mathrm{PO}_{4}{ }^{3-} \text { eq) }\right.\end{array}$ & 0.26 & 0.26 & 0.02 & 9.56 & 0.21 & 0.31 & $7.8 \cdot 10^{-4}$ \\
\hline $\begin{array}{c}\text { Human toxicity } \\
\text { (HT) } \\
\text { (kg 1,4-DCB eq) }\end{array}$ & 0.79 & 0.61 & 0.66 & 82.80 & 0.28 & 2.48 & 0.02 \\
\hline $\begin{array}{l}\text { Photochemical } \\
\text { Oxidation } \\
\text { Formation } \\
\text { (POF) } \\
\text { (kg NMVOC) }\end{array}$ & 0.01 & 0.01 & $1.10^{-3}$ & 12.02 & 0.01 & 0.01 & $3.5 \cdot 10^{-5}$ \\
\hline 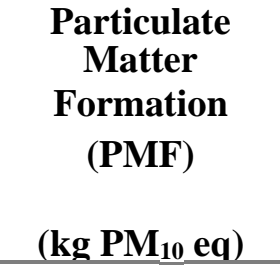 & 0.01 & 0.01 & $6.3 \cdot 10^{-4}$ & 9.70 & 0.01 & 0.01 & $2 \cdot 10^{-5}$ \\
\hline $\begin{array}{l}\text { Terrestrial } \\
\text { Ecotoxicity } \\
\text { (TET) }\end{array}$ & $\begin{array}{l}8 \cdot 10^{-} \\
5\end{array}$ & $7.6 \cdot 10^{-5}$ & $1.9 \cdot 10^{-5}$ & 24.28 & 0.00 & $1.3 \cdot 10^{-4}$ & $6.1 \cdot 10^{-7}$ \\
\hline
\end{tabular}

(kg 1,4-DCB eq)

Freshwater

Ecotoxicity

(FET)

$0.06 \quad 0.06$

0.02

28.98

0.03

0.10

$5.3 \cdot 10^{-4}$

(kg 1,4-DCB eq)

Marine

Ecotoxicity

(MET)

$\begin{array}{lll}0.05 & 0.05 & 0.01\end{array}$

28.71

0.03

0.09

$4.7 \cdot 10^{-4}$ 
54

55

56

57

59

(kg 1,4-DCB eq)

Fossil Depletion

(FD)

0.80

0.76

0.21

26.81

0.51

1.27

0.01

(kg oil eq) 
Table S3. Uncertainty values for the PP2 reactor $\left(\mathrm{V}=1.2 \mathrm{~m}^{3}\right)$. Acronyms: $\mathrm{CV}$ : coefficient of variation; SEM: standard error of the mean.

\begin{tabular}{|c|c|c|c|c|c|c|c|}
\hline $\begin{array}{c}\text { Impact } \\
\text { Categories }\end{array}$ & Mean & Median & $\begin{array}{l}\text { Standard } \\
\text { deviation }\end{array}$ & $\mathrm{CV}$ & $2.5 \%$ & $97.5 \%$ & SEM \\
\hline $\begin{array}{c}\text { Climate change } \\
(\mathrm{CC}) \\
(\mathrm{kg} \mathrm{CO} \\
\end{array}$ & 6.25 & 6.23 & 0.14 & 2.19 & 6.04 & 6.57 & $4.3 \cdot 10^{-3}$ \\
\hline $\begin{array}{l}\text { Ozone depletion } \\
\text { (OD) } \\
\text { (kg CFC-11 eq) }\end{array}$ & $3.0 \cdot 10^{-7}$ & $2.9 \cdot 10^{-7}$ & $5.9 \cdot 10^{-8}$ & 19.91 & $2.0 \cdot 10^{-7}$ & $4.5 \cdot 10^{-7}$ & $1.9 \cdot 10^{-9}$ \\
\hline $\begin{array}{c}\text { Terrestrial } \\
\text { acidification } \\
(\mathrm{TA}) \\
\left(\mathrm{kg} \mathrm{SO}_{2} \mathrm{eq}\right)\end{array}$ & 0.01 & 0.01 & $9.5 \cdot 10^{-4}$ & 7.86 & 0.01 & 0.01 & $3.0 \cdot 10^{-5}$ \\
\hline $\begin{array}{c}\text { Eutrophication } \\
(\mathrm{EP}) \\
\left(\mathrm{kg} \mathrm{PO}_{4}{ }^{3-} \mathrm{eq}\right) \\
\end{array}$ & 0.25 & 0.25 & 0.03 & 12.09 & 0.19 & 0.31 & $9.7 \cdot 10^{-4}$ \\
\hline $\begin{array}{c}\text { Human toxicity } \\
\text { (HT) } \\
\text { (kg 1,4-DCB eq) }\end{array}$ & 0.51 & 0.40 & 0.38 & 74.24 & 0.19 & 1.47 & 0.01 \\
\hline $\begin{array}{c}\text { Photochemical } \\
\text { Oxidation } \\
\text { Formation } \\
\text { (POF) } \\
\text { (kg NMVOC) }\end{array}$ & 0.01 & 0.01 & $7.3 \cdot 10^{-4}$ & 11.91 & $4.9 \cdot 10^{-3}$ & 0.01 & $2.3 \cdot 10^{-5}$ \\
\hline $\begin{array}{c}\text { Particulate } \\
\text { Matter } \\
\text { Formation } \\
(\text { PMF) } \\
\text { (kg PM } \text { PM }_{10} \text { eq) }\end{array}$ & $4.3 \cdot 10^{-3}$ & $4.2 \cdot 10^{-3}$ & $4.0 \cdot 10^{-4}$ & 9.42 & $3.7 \cdot 10^{-3}$ & 0.01 & $1.3 \cdot 10^{-5}$ \\
\hline $\begin{array}{c}\text { Terrestrial } \\
\text { Ecotoxicity } \\
\text { (TET) } \\
\text { (kg 1,4-DCB eq) }\end{array}$ & $5.2 \cdot 10^{-5}$ & $5.0 \cdot 10^{-5}$ & $1.2 \cdot 10^{-5}$ & 22.51 & $3.6 \cdot 10^{-5}$ & $7.8 \cdot 10^{-5}$ & $3.7 \cdot 10^{-7}$ \\
\hline $\begin{array}{c}\begin{array}{c}\text { Freshwater } \\
\text { Ecotoxicity } \\
\text { (FET) }\end{array} \\
\text { (kg 1,4-DCB eq) }\end{array}$ & 0.04 & 0.04 & 0.01 & 28.27 & 0.02 & 0.06 & $3.4 \cdot 10^{-4}$ \\
\hline $\begin{array}{c}\text { Marine } \\
\text { Ecotoxicity }\end{array}$ & 54 & & (MET) & & & & \\
\hline
\end{tabular}




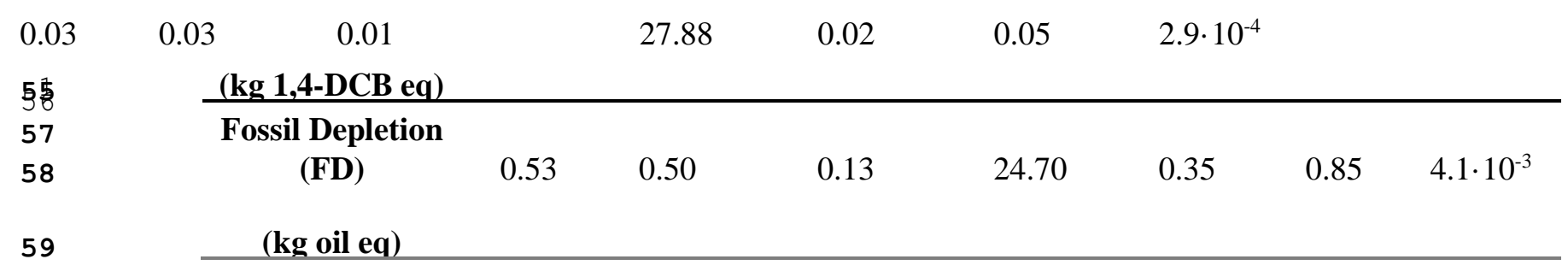


Table S4. Uncertainty values for the FS reactor $\left(\mathrm{V}=97 \mathrm{~m}^{3}\right)$. Acronyms: CV: coefficient of variation; SEM: standard error of the mean.

\begin{tabular}{|c|c|c|c|c|c|c|c|}
\hline $\begin{array}{c}\text { Impact } \\
\text { Categories }\end{array}$ & Mean & Median & $\begin{array}{l}\text { Standard } \\
\text { deviation }\end{array}$ & $\mathrm{CV}$ & $2.5 \%$ & $97.5 \%$ & SEM \\
\hline $\begin{array}{c}\text { Climate change } \\
(\mathrm{CC}) \\
\left(\mathrm{kg} \mathrm{CO}_{2} \mathrm{eq}\right) \\
\end{array}$ & 4.61 & 4.61 & 0.05 & 1.03 & 4.55 & 4.72 & $1.5 \cdot 10^{-3}$ \\
\hline $\begin{array}{c}\text { Ozone depletion } \\
\text { (OD) } \\
\text { (kg CFC-11 eq) }\end{array}$ & $1.0 \cdot 10^{-7}$ & $9.9 \cdot 10^{-7}$ & $2.0 \cdot 10^{-8}$ & 19.94 & $6.8 \cdot 10^{-8}$ & $1.5 \cdot 10^{-7}$ & $6.4 \cdot 10^{-10}$ \\
\hline $\begin{array}{c}\text { Terrestrial } \\
\text { acidification } \\
\text { (TA) } \\
\left(\mathrm{kg} \mathrm{SO}_{2} \mathrm{eq}\right)\end{array}$ & $4.2 \cdot 10^{-3}$ & $4.1 \cdot 10^{-3}$ & $3.3 \cdot 10^{-4}$ & 7.86 & $3.7 \cdot 10^{-4}$ & 0.00 & $1.0 \cdot 10^{-5}$ \\
\hline $\begin{array}{c}\text { Eutrophication } \\
(\mathrm{EP}) \\
\left(\mathrm{kg} \mathrm{PO}{ }^{3-} \mathrm{eq}\right) \\
\end{array}$ & 0.28 & 0.28 & 0.03 & 10.26 & 0.22 & 0.34 & $9.2 \cdot 10^{-4}$ \\
\hline $\begin{array}{c}\underset{(H T)}{\text { Human toxicity }} \\
\text { (kg 1,4-DCB eq) }\end{array}$ & 0.17 & 0.14 & 0.14 & 81.02 & 0.06 & 0.49 & $4.4 \cdot 10^{-3}$ \\
\hline $\begin{array}{c}\text { Photochemical } \\
\text { Oxidation } \\
\text { Formation } \\
\text { (POF) } \\
\text { (kg NMVOC) }\end{array}$ & $2.1 \cdot 10^{-3}$ & $2.1 \cdot 10_{-3}$ & $2.6 \cdot 10^{-4}$ & 12.09 & $1.7 \cdot 10^{-3}$ & $2.7 \cdot 10^{-3}$ & $8.1 \cdot 10^{-6}$ \\
\hline $\begin{array}{l}\text { Particulate } \\
\text { Matter } \\
\text { Formation } \\
(\text { PMF }) \\
(\text { kg PM } \\
\text { 10 eq })\end{array}$ & $1.5 \cdot 10^{-3}$ & $1.5 \cdot 10^{-3}$ & $1.4 \cdot 10^{-4}$ & 9.37 & $1.3 \cdot 10^{-3}$ & $1.8 \cdot 10^{-3}$ & $4.4 \cdot 10^{-6}$ \\
\hline $\begin{array}{l}\text { Terrestrial } \\
\text { Ecotoxicity } \\
\text { (TET) }\end{array}$ & $1.8 \cdot 10^{-5}$ & $1.7 \cdot 10^{-5}$ & $4.1 \cdot 10^{-6}$ & 23.04 & $1.3 \cdot 10^{-5}$ & $2.8 \cdot 10^{-5}$ & $1.3 \cdot 10^{-7}$ \\
\hline $\begin{array}{l}\text { Freshwater } \\
\text { Ecotoxicity } \\
(\text { FET) } \\
\text { (kg 1,4-DCB eq) }\end{array}$ & 0.01 & 0.01 & $3.8 \cdot 10^{-3}$ & 29.33 & 0.01 & 0.02 & $1.2 \cdot 10^{-4}$ \\
\hline $\begin{array}{c}\text { Marine } \\
\text { Ecotoxicity } \\
\text { (MET) }\end{array}$ & 0.01 & 0.01 & $3.3 \cdot 10^{-3}$ & 29.06 & 0.01 & 0.02 & $1.1 \cdot 10^{-4}$ \\
\hline
\end{tabular}


Fossil Depletion

(FD)

0.18

0.17

$0.05 \quad 26.00$

0.12

0.29

$1.5 \cdot 10^{-3}$

(kg oil eq) 